\title{
Crustal contamination and diversity of magma sources in the northwestern Ethiopian volcanic province
}

\author{
Daniel Meshesha and Ryuichi SHINJO \\ Department of Physics and Earth Sciences, University of the Ryukyus, \\ Senbaru 1, Nishihara, Okinawa 903-0213, Japan
}

\begin{abstract}
Geochemical and isotopic data are presented for Bure volcanic rocks from the northwestern Ethiopian plateau to investigate the processes involved in the genesis of the erupted magma and the nature of mantle source compositions during plume-induced continental rifting. The Bure area is mainly composed of flood basalts (30-25 $\mathrm{Ma}$ ), ranging from transitional tholeiite to alkaline basalts, with a probable Quaternary alkaline basalt single lava flow, scoria cones and trachyte plugs. The transitional tholeiites have variable incompatible elements and isotopic ratios $\left({ }^{87} \mathrm{Sr} /{ }^{86} \mathrm{Sr}=0.70329-0.70429,{ }^{143} \mathrm{Nd} /{ }^{144} \mathrm{Nd}=0.51281-0.51304\right.$ and $\left.{ }^{206} \mathrm{~Pb} /{ }^{204} \mathrm{~Pb}=18.36-19.08\right)$. In contrast, the alkaline basalts display a homogeneous incompatible element and $\mathrm{Sr}-\mathrm{Nd}$ isotopic ratios $\left({ }^{87} \mathrm{Sr} /{ }^{86} \mathrm{Sr}\right.$ $=0.70311-0.70363$ and $\left.{ }^{143} \mathrm{Nd} /{ }^{144} \mathrm{Nd}=0.51279-0.51288\right)$ with a wide range of $\mathrm{Pb}$ isotopes $\left({ }^{206} \mathrm{~Pb} /{ }^{204} \mathrm{~Pb}=18.91-\right.$ 19.83). Isotope and trace element variations within the Bure lavas reflect the involvement of: 1) an intrinsic isotopically depleted plume component, 2) a plume component having radiogenic $\mathrm{Pb}$ isotope and 3) an enriched crustal component. The first and third components played a significant contribution in the initial stage of plume-induced continental flood basalt magmatism.
\end{abstract}

Keywords: East African rift, $\mathrm{Sr}-\mathrm{Nd}-\mathrm{Pb}$ isotopes, Afar plume, Crustal contamination, Continental flood basalts

\section{INTRODUCTION}

The magmatism along the NNE-SSW running EthiopianKenyan rift, the encircling plateaus and the Afar Depression together represent one of the largest, currently active igneous provinces in the East Africa (Fig. 1a). The East African Rift System (EARS) forms the southwestern part of the Afro-Arabian triple junction that comprises the Red Sea and the Gulf of Aden oceanic rift, which were formed by the separation of the Arabian and African plates (Fig. 1a). EARS is several hundred kilometers long and characterized by widely distributed volcanic provinces that were initiated in the Eocene to Oligocene as a result of lithospheric extension due to the domal uplift of the surrounding regions. It is widely accepted that the distribution and timing of magmatism and uplift of the entire area resulted from the upwelling of a complex, heterogeneous African mantle plume (Kieffer et al., 2004 and references therein).

The extensive flood basalt plateaus in Ethiopia, Saudi Arabia and Yemen well represented part of this complexity. The continental flood basalt (CFB) magma-

doi: $10.2465 /$ jmps.061129

R. Shinjo,rshinjo@sci.u-ryukyu.ac.jp Corresponding author tism in these regions is mainly divided into two groups: 1) an older group of predominantly transitional to subalkaline flood basalts (pre-rift volcanism) and 2) a younger group consisting of mainly alkaline volcanics (syn- to post-rift volcanism). Among these plateaus, the Ethiopian one is ideal for studying the nature of the mantle sources of CFBs as it represents a complete record of the flood basalt volcanism, from its initial phase to the onset of continental rifting.

Three mantle sources (old subcontinental lithosphere, the HIMU-type (high $\mu$ ) Afar mantle plume and the depleted mantle) have been proposed as potential sources for the Ethiopian CFBs (e.g., Vidal et al., 1991; Deniel et al., 1994; Stewart and Rogers, 1996). Moreover, these basalts suffered variable degrees of crustal contamination (White and McKenzie, 1989; Baker et al., 1996; Pik et al., 1998, 1999). The geochemistry of Ethiopian CFB magmas, therefore, reflects a complex interplay of source heterogeneity, variable extents of melting, and evolution of the magmas prior to eruption.

In this paper, we present major and trace elements and $\mathrm{Sr}-\mathrm{Nd}-\mathrm{Pb}$ isotope data for volcanic rocks from the Bure area with new $\mathrm{K}-\mathrm{Ar}$ dating results. The Bure area is located in the western part of the northwestern Ethiopian plateau of the East African CFB province (Fig. 1a), where 


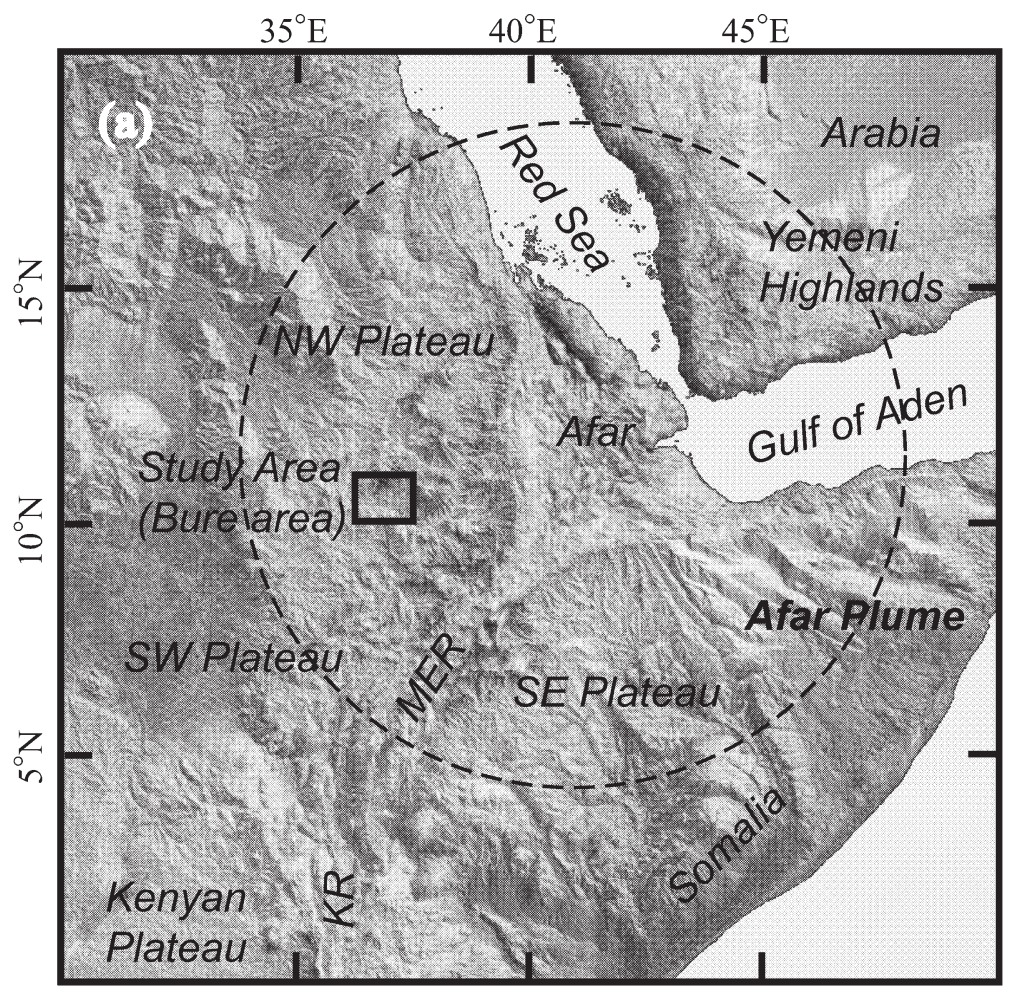

Figure 1. Location of the study sites: (a) shaded relief map of northeastern Africa and Arabia (NASA SRTM30) illustrating the position of the three rifts (Main Ethiopian Rift, MER, Gulf of Aden and Red Sea), as well as the Ethiopian and Yemeni plateaus, which surround the Afar Depression, with the Bure area indicated; (b) simplified geological map of the Bure area; topographic contour lines (interval $=500$ m) are indicated; $\mathrm{FB}=$ flood basalts. Basement rocks include Precambrian gneisses, low-grade metamorphic rocks and granitoids.

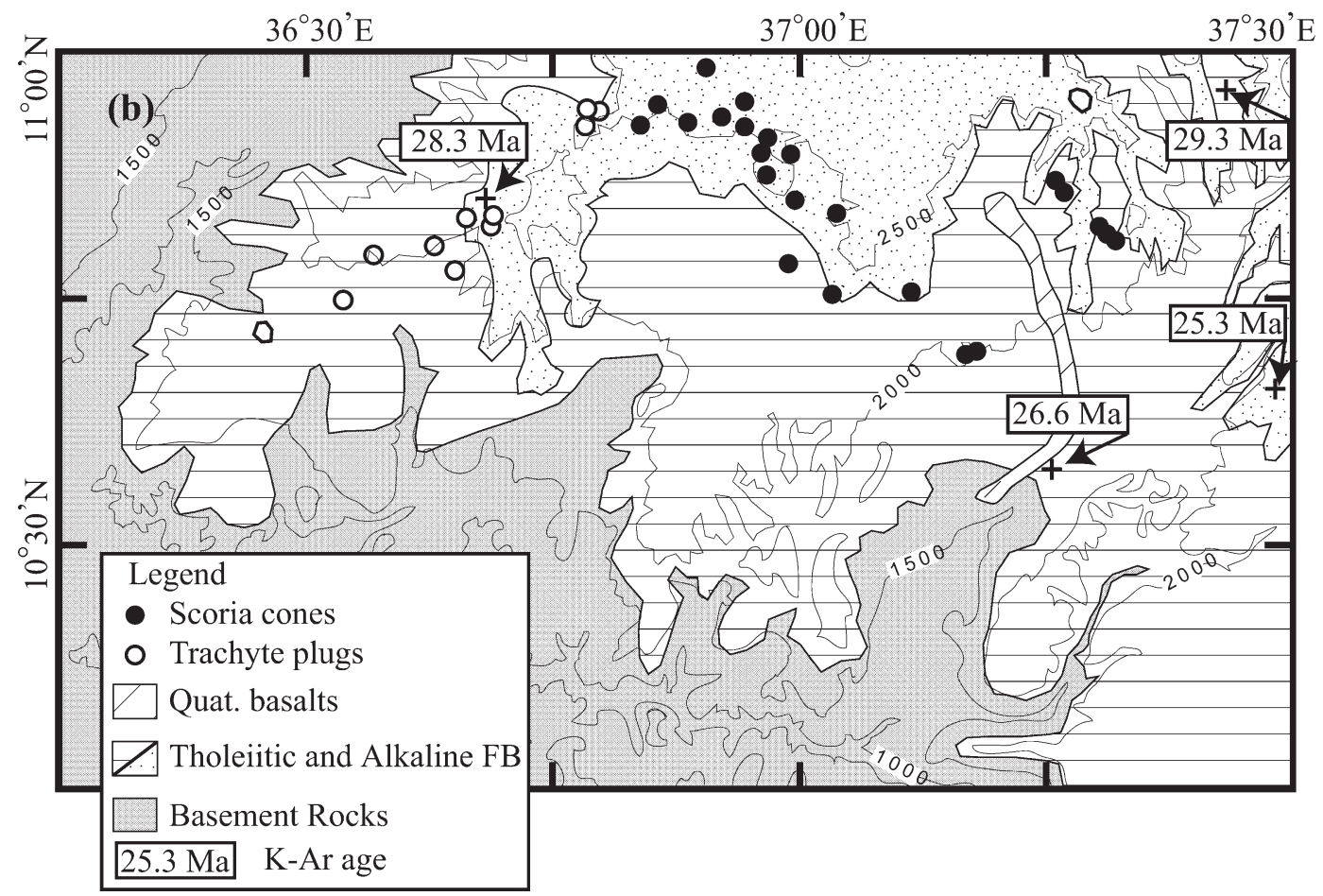

both pre-rift and post-rift basalts are widely distributed. Although Pik et al. (1998, 1999) and Kieffer et al. (2004) reported detailed geochemical data for basalts in the northwestern Ethiopian plateau, there are no such data for the Bure volcanic rocks. Our dataset has been used to investigate the nature of asthenospheric and lithospheric mantle sources involved in the genesis of these magmas and the compositional effects of interactions between plume melts and crustal materials. Geochemical variation is also discussed in the context of the geodynamic evolution of plume-induced continental rifting. 
Table 1. Major and trace element contents by XRF and modal compositions of volcanic rocks from the Bure area

\begin{tabular}{|c|c|c|c|c|c|c|c|c|c|c|c|}
\hline \multirow{2}{*}{$\begin{array}{l}\text { Type } \\
\text { Sample No }\end{array}$} & \multicolumn{3}{|c|}{ Transitional tholeiite basalts } & \multirow[b]{2}{*}{$\begin{array}{c}\text { ASW- } \\
503\end{array}$} & \multirow[b]{2}{*}{ TL-208 } & \multirow[b]{2}{*}{ TL-229 } & \multirow[b]{2}{*}{ TL-253 } & \multirow[b]{2}{*}{$\begin{array}{r}\text { EH- } \\
235 \mathrm{~A}\end{array}$} & \multirow[b]{2}{*}{ AN-201 } & \multirow[b]{2}{*}{$\begin{array}{c}\mathrm{MH}- \\
4510 \mathrm{~A} \\
\end{array}$} & \multirow[b]{2}{*}{$\begin{array}{l}\text { MH- } \\
4521 \\
\end{array}$} \\
\hline & $\begin{array}{c}\text { TD- } \\
1228 \mathrm{~A}\end{array}$ & TD-1202 & TD-1239 & & & & & & & & \\
\hline $\mathrm{SiO}_{2}(\mathrm{wt} \%)$ & 50.56 & 51.62 & 46.93 & 51.39 & 52.85 & 50.11 & 48.90 & 48.52 & 47.01 & 49.18 & 49.50 \\
\hline $\mathrm{TiO}_{2}$ & 2.441 & 1.706 & 1.260 & 2.312 & 2.231 & 2.092 & 2.306 & 2.126 & 1.252 & 3.500 & 3.544 \\
\hline $\mathrm{Al}_{2} \mathrm{O}_{3}$ & 13.88 & 14.47 & 14.29 & 14.24 & 14.20 & 15.63 & 14.44 & 15.92 & 15.53 & 13.11 & 13.99 \\
\hline $\mathrm{Fe}_{2} \mathrm{O}_{3}$ & 13.91 & 11.94 & 11.62 & 13.39 & 12.21 & 12.90 & 13.74 & 11.98 & 11.98 & 16.51 & 13.27 \\
\hline $\mathrm{MnO}$ & 0.21 & 0.17 & 0.18 & 0.18 & 0.19 & 0.19 & 0.19 & 0.18 & 0.18 & 0.24 & 0.22 \\
\hline $\mathrm{MgO}$ & 5.00 & 6.05 & 11.14 & 5.29 & 3.77 & 5.16 & 5.79 & 6.56 & 8.65 & 3.89 & 4.73 \\
\hline $\mathrm{CaO}$ & 9.67 & 10.44 & 9.64 & 8.98 & 6.76 & 10.83 & 11.04 & 10.69 & 10.48 & 8.59 & 8.77 \\
\hline $\mathrm{Na}_{2} \mathrm{O}$ & 2.94 & 2.71 & 2.89 & 2.86 & 3.36 & 2.56 & 2.62 & 2.62 & 2.14 & 2.94 & 3.07 \\
\hline $\mathrm{K}_{2} \mathrm{O}$ & 0.62 & 0.44 & 0.64 & 0.94 & 2.35 & 0.48 & 0.45 & 0.74 & 0.36 & 1.18 & 1.05 \\
\hline $\mathrm{P}_{2} \mathrm{O}_{5}$ & 0.214 & 0.130 & 0.197 & 0.268 & 0.807 & 0.176 & 0.197 & 0.229 & 0.114 & 0.416 & 0.811 \\
\hline LOI & 0.46 & 0.34 & 0.35 & 2.46 & 1.22 & 0.72 & 0.93 & 2.07 & 3.42 & 0.87 & 1.18 \\
\hline Total & 99.90 & 100.02 & 99.14 & 102.31 & 99.94 & 100.85 & 100.60 & 101.64 & 101.12 & 100.43 & 100.13 \\
\hline \multicolumn{12}{|l|}{ XRF data } \\
\hline $\mathrm{Ba}(\mathrm{ppm})$ & 134 & 149 & 236 & 308 & 1665 & 132 & 86 & 194 & 754 & 232 & 797 \\
\hline $\mathrm{Ce}$ & 30 & 32 & 18 & 55 & 120 & 18 & 21 & 30 & 8 & 62 & 69 \\
\hline Co & 42 & 39 & 60 & 43 & 29 & 39 & 44 & 39 & 46 & 38 & 34 \\
\hline $\mathrm{Cr}$ & 23 & 71 & 457 & 45 & 19 & 56 & 45 & 184 & 326 & 19 & 48 \\
\hline $\mathrm{Nb}$ & 7.4 & 5.8 & 21.5 & 10.3 & 17.7 & 6.7 & 10.0 & 12.9 & 4.3 & 18.7 & 17.8 \\
\hline $\mathrm{Ni}$ & 22 & 32 & 283 & 63 & 12 & 29 & 46 & 100 & 134 & 12 & 12 \\
\hline $\mathrm{Pb}$ & 5 & 4 & 2 & 4 & 12 & 4 & 2 & 4 & 3 & 7 & 6 \\
\hline $\mathrm{Rb}$ & 14 & 8 & 14 & 18 & 28 & 13 & 9 & 13 & 8 & 24 & 18 \\
\hline $\mathrm{Sr}$ & 264 & 257 & 333 & 351 & 742 & 299 & 272 & 337 & 350 & 264 & 560 \\
\hline Th & 1 & 3 & 3 & 2 & 3 & 2 & 2 & 4 & _- & 5 & 4 \\
\hline V & 392 & 263 & 191 & 310 & 227 & 368 & 372 & 345 & 251 & 397 & 338 \\
\hline Y & 31 & 27 & 22 & 33 & 38 & 26 & 25 & 25 & 21 & 42 & 31 \\
\hline $\mathrm{Zr}$ & 145 & 114 & 90 & 181 & 317 & 127 & 130 & 154 & 94 & 222 & 158 \\
\hline \multicolumn{12}{|c|}{ Phenocryst (\%) } \\
\hline Plagioclase & & 6.60 & & 6.00 & & 10.00 & 10.90 & 15.00 & & & \\
\hline Olivine & & & 9.80 & & 10.00 & & & & & & \\
\hline Clinopyroxer & & & & 10.60 & 5.00 & & 0.20 & 6.90 & & & \\
\hline Orthopyroxe & & & & 7.00 & & & & & & & \\
\hline Groundmass & & 93.40 & 90.20 & 76.40 & 85.00 & 90.00 & 88.90 & 78.10 & & & \\
\hline
\end{tabular}

LOI, loss on ignition; $\mathrm{Fe}_{2} \mathrm{O}_{3}$, total $\mathrm{Fe}_{2} \mathrm{O}_{3}$.

For normative calculation $\mathrm{Fe}_{2} \mathrm{O}_{3} / \mathrm{FeO}=0.15$ is assumed.

\section{GEOLOGICAL SETTING}

The Ethiopian volcanic province is composed of Tertiary (Trap series) and Quaternary (Aden series) basaltic successions (Mohr, 1963) with thicknesses varying from 700 to 2,000 $\mathrm{m}$ at the plateau-rift margins (Berhe et al., 1987) and about $300000 \mathrm{~km}^{3}$ (Mohr, 1963; Hart et al., 1989; Tefera et al., 1996). The volcanic province is subdivided into three major geographical and geomorphological parts (Fig. 1a): the Ethiopian plateaus (northwestern, southwestern and southeastern), the Main Ethiopian Rift (MER) and the Afar Rift (Kazmin, 1979; Berhe et al., 1987; Hart et al., 1989). Although the post-rift volcanism has been concentrated mainly along the axis of MER, it also occurred in the Tana graben in the NW plateau region (Kazmin, 1972, 1979) and along the Yere-Tulu Wellel volcano-tectonic lineaments between the northwestern and southwestern plateaus (Abebe et al., 1998).

The Ethiopian flood basalts occurred in three main episodes $30 \mathrm{Ma}, 22-12 \mathrm{Ma}$ and $<5 \mathrm{Ma}$ (Stewart and Rogers, 1996; Kieffer et al., 2004). The occurrence of the latest stage volcanism outside the MER might be related to the development of new rift and fracture zones (Davidson and Rex, 1980). 
Table 1. (Continued)

\begin{tabular}{|c|c|c|c|c|c|c|c|c|c|c|c|}
\hline \multicolumn{3}{|l|}{ Type } & \multicolumn{9}{|c|}{ Alkaline basalts } \\
\hline Sample No & $\begin{array}{l}\text { WH- } \\
3496\end{array}$ & $\mathrm{TN}-28$ & $\begin{array}{c}\text { TD- } \\
1034 \mathrm{~B}\end{array}$ & SM-172 & SM-120 & $\begin{array}{l}\text { SOG- } \\
3136 \\
\end{array}$ & $\begin{array}{l}\text { SOG- } \\
3061 \mathrm{~B}\end{array}$ & $\begin{array}{l}\text { SOG- } \\
3104 \\
\end{array}$ & $\mathrm{TN}-85$ & $\begin{array}{l}\text { SOG- } \\
3091 \\
\end{array}$ & $\begin{array}{l}\text { SOG- } \\
3005 \\
\end{array}$ \\
\hline $\mathrm{SiO}_{2}(\mathrm{wt} \%)$ & 47.07 & 43.20 & 46.84 & 47.21 & 49.68 & 44.55 & 58.31 & 57.58 & 49.99 & 44.75 & 44.37 \\
\hline $\mathrm{TiO}_{2}$ & 3.723 & 3.894 & 3.142 & 2.505 & 2.260 & 2.978 & 1.009 & 0.428 & 2.167 & 3.735 & 2.430 \\
\hline $\mathrm{Al}_{2} \mathrm{O}_{3}$ & 13.88 & 14.18 & 16.46 & 16.72 & 16.97 & 15.72 & 18.32 & 18.09 & 15.20 & 15.09 & 12.52 \\
\hline $\mathrm{Fe}_{2} \mathrm{O}_{3}$ & 14.04 & 13.39 & 14.48 & 12.90 & 10.43 & 13.03 & 4.75 & 6.12 & 12.52 & 14.88 & 11.50 \\
\hline $\mathrm{MnO}$ & 0.21 & 0.19 & 0.21 & 0.18 & 0.21 & 0.19 & 0.23 & 0.38 & 0.18 & 0.23 & 0.17 \\
\hline $\mathrm{MgO}$ & 6.05 & 8.34 & 4.38 & 5.39 & 4.28 & 7.96 & 1.06 & 0.90 & 4.66 & 4.87 & 12.01 \\
\hline $\mathrm{CaO}$ & 10.26 & 10.34 & 6.60 & 7.91 & 6.32 & 8.88 & 2.93 & 1.72 & 9.10 & 8.05 & 11.53 \\
\hline $\mathrm{Na}_{2} \mathrm{O}$ & 2.77 & 2.79 & 3.82 & 3.71 & 4.32 & 3.09 & 6.62 & 6.78 & 3.38 & 3.52 & 2.05 \\
\hline $\mathrm{K}_{2} \mathrm{O}$ & 0.49 & 0.67 & 1.39 & 1.00 & 2.40 & 0.98 & 3.96 & 4.87 & 0.93 & 1.86 & 0.82 \\
\hline $\mathrm{P}_{2} \mathrm{O}_{5}$ & 0.808 & 0.568 & 0.532 & 0.585 & 1.027 & 0.599 & 0.240 & 0.241 & 0.278 & 0.907 & 0.379 \\
\hline LOI & 0.87 & 2.89 & 1.88 & 1.24 & 2.02 & 2.06 & 1.34 & 1.63 & 1.77 & 2.28 & 2.60 \\
\hline Total & 100.17 & 100.45 & 99.73 & 99.35 & 99.92 & 100.04 & 98.77 & 98.74 & 100.17 & 100.18 & 100.39 \\
\hline \multicolumn{12}{|l|}{$\mathrm{XRF}$ data } \\
\hline $\mathrm{Ba}(\mathrm{ppm})$ & 799 & 476 & 569 & 426 & 945 & 354 & 1516 & 883 & 318 & 624 & 325 \\
\hline $\mathrm{Ce}$ & 57 & 71 & 67 & 64 & 120 & 68 & 140 & 198 & 57 & 109 & 40 \\
\hline Co & 39 & 46 & 41 & 44 & 21 & 52 & 6 & 8 & 41 & 37 & 54 \\
\hline $\mathrm{Cr}$ & 61 & 241 & 10 & 21 & 16 & 27 & 5 & 7 & 20 & 18 & 767 \\
\hline $\mathrm{Nb}$ & 13.6 & 56.5 & 36.4 & 29.7 & 76 & 36 & 128 & 195 & 22 & 81 & 30 \\
\hline $\mathrm{Ni}$ & 30 & 83 & 3 & 20 & 8 & 79 & 8 & 6 & 20 & 5 & 255 \\
\hline $\mathrm{Pb}$ & 5 & 3 & 5 & 6 & 5 & 4 & 8 & 11 & 5 & 4 & 3 \\
\hline $\mathrm{Rb}$ & 13 & 15 & 23 & 17 & 46 & 18 & 89 & 119 & 18 & 59 & 19 \\
\hline $\mathrm{Sr}$ & 677 & 740 & 520 & 556 & 1133 & 601 & 1077 & 268 & 425 & 927 & 432 \\
\hline Th & 2 & 3 & 2 & 2 & 6 & 3 & 9 & 15 & 4 & 5 & 4 \\
\hline V & 353 & 302 & 162 & 169 & 149 & 233 & 17 & 4 & 340 & 168 & 284 \\
\hline $\mathrm{Y}$ & 25 & 24 & 33 & 31 & 26 & 28 & 29 & 30 & 28 & 29 & 22 \\
\hline $\mathrm{Zr}$ & 133 & 230 & 226 & 182 & 231 & 188 & 312 & 427 & 198 & 304 & 163 \\
\hline \multicolumn{12}{|l|}{ Phenocryst (\%) } \\
\hline Plagioclase & & & 20.90 & 9.20 & 13.10 & 1.50 & 1.30 & 0.60 & 7.60 & & 0.30 \\
\hline Olivine & & 8.00 & & & 1.20 & 12.20 & & & & 2.70 & 7.00 \\
\hline Clinopyroxene & & 2.00 & & 1.30 & 0.70 & 0.10 & & 2.80 & & & 10.20 \\
\hline Fe-Ti oxides & & & & & 2.00 & & 0.30 & 0.40 & & 8.80 & \\
\hline Groundmass & & 90.00 & 79.10 & 89.50 & 83.00 & 86.20 & 98.40 & 96.20 & 92.40 & 88.50 & 82.50 \\
\hline
\end{tabular}

LOI, loss on ignition; $\mathrm{Fe}_{2} \mathrm{O}_{3}$, total $\mathrm{Fe}_{2} \mathrm{O}_{3}$.

For normative calculation $\mathrm{Fe}_{2} \mathrm{O}_{3} / \mathrm{FeO}=0.15$ is assumed.

Although the Ethiopian CFBs have been the subject of numerous publications (e.g., Mohr and Zanettin, 1988; Hart et al., 1989; Schilling et al., 1992; Deniel et al., 1994; Stewart and Rogers, 1996; Barrat et al., 1998; Pik et al., 1999; Barrat et al., 2003; Kieffer et al., 2004), there are still Ethiopian flood basalt regions poorly known. The Bure area is one of them. In this region, Cenozoic volcanic rocks lie unconformably on Precambrian basement (Fig. 1b).

New $\mathrm{K}$-Ar ages, commercially obtained from four representative Bure volcanic rock samples (see Appendix for data; the locations of dated samples are shown in Fig. 1b) indicate 29.3-26.6 Ma for transitional tholeiite CFBs and 28.3-25.3 Ma for alkaline CFBs. Although previous studies have suggested that the East African flood basalts were erupted about $30 \mathrm{Ma}$ over a period of 1-2 My (e.g., Baker et al., 1996; Hofmann et al., 1997), ages obtained in this study imply a much longer period (30-25 Ma) of flood basalts activity in the region. Such a longer age distribution appears compatible with the compilation of Kieffer et al. (2004). Although there are no available age data for recent basalt flow, scoria and trachyte plugs, the field occurrence of these rocks suggests that their formation took place in the Quaternary. 
Table 1. (Continued)

\begin{tabular}{|c|c|c|c|c|c|}
\hline & \multicolumn{2}{|c|}{ Quat. basalts } & \multicolumn{3}{|c|}{ Trachyte plugs } \\
\hline $\begin{array}{l}\text { SOG- } \\
3043\end{array}$ & TD-1003 & $\begin{array}{l}\text { SOG- } \\
3157\end{array}$ & $\begin{array}{c}\text { TD- } \\
1136 \mathrm{~A} 2\end{array}$ & $\begin{array}{c}\text { TD- } \\
1135 \mathrm{~B}\end{array}$ & SM-113 \\
\hline 45.72 & 46.56 & 48.54 & 64.01 & 63.91 & 63.98 \\
\hline 1.931 & 1.743 & 1.755 & 0.171 & 0.174 & 0.407 \\
\hline 14.72 & 14.91 & 16.77 & 17.09 & 17.01 & 15.85 \\
\hline 11.00 & 10.91 & 11.72 & 4.11 & 4.00 & 4.44 \\
\hline 0.18 & 0.17 & 0.16 & 0.14 & 0.09 & 0.19 \\
\hline 9.63 & 10.05 & 6.14 & 0.08 & 0.05 & 0.16 \\
\hline 10.14 & 10.27 & 10.42 & 0.40 & 0.59 & 0.34 \\
\hline 3.97 & 3.01 & 3.28 & 6.78 & 6.8 & 7.31 \\
\hline 1.47 & 1.17 & 1.00 & 5.36 & 5.49 & 5.05 \\
\hline 0.495 & 0.293 & 0.279 & 0.038 & 0.068 & 0.046 \\
\hline 0.36 & 0.14 & 0.67 & 0.77 & 0.99 & 0.75 \\
\hline 99.61 & 99.22 & 100.74 & 98.95 & 99.17 & 98.53 \\
\hline 593 & 366 & 347 & 162 & 123 & 32 \\
\hline 72 & 43 & 50 & 320 & 354 & 338 \\
\hline 45 & 51 & 34 & 4 & 4 & 4 \\
\hline 315 & 321 & 158 & 6 & 5 & 8 \\
\hline 75 & 32 & 26 & 176 & 182 & 356 \\
\hline 187 & 184 & 51 & 16 & 13 & 11 \\
\hline 4 & 2 & 4 & 12 & 13 & 20 \\
\hline 43 & 24 & 18 & 123 & 145 & 193 \\
\hline 733 & 518 & 518 & 14 & 14 & 19 \\
\hline 6 & 2 & 3 & 15 & 15 & 29 \\
\hline 199 & 227 & 219 & 4 & 3 & 6 \\
\hline 20 & 17 & 22 & 90 & 83 & 50 \\
\hline 169 & 135 & 133 & 1072 & 1144 & 944 \\
\hline & 0.20 & 2.00 & & & \\
\hline 7.20 & 15.60 & 8.00 & & & \\
\hline & 0.10 & & & & \\
\hline 92.80 & 84.10 & 90.00 & & & \\
\hline
\end{tabular}

Using a combination of stratigraphic information and geochronological and petrological data, the volcanic rocks of the Bure area can be deduced as: 1) transitional tholeiitic, 2) alkaline CFBs formed in the Oligocene and 3) Quaternary basalts, scoria cones and trachyte plugs.

\section{PETROGRAPHY OF VOLCANIC ROCKS FROM THE BURE AREA}

Both the transitional tholeiite and alkaline CFBs have porphyritic to aphyric textures (Table 1). Ophitic and subophitic textures are also observed in the transitional tholeiites. Most CFBs samples contain phenocrysts of olivine (altered to iddingsite along the rims and fractures), clino- pyroxene and plagioclase set in a groundmass, which has the same phases plus opaque minerals and ranges from holocrystalline to intergranular and trachytic. In the transitional tholeiite CFBs phenocrysts of orthopyroxene may occur. The Quaternary basalt consists of a single lava flow with pahoehoe structure and occurs along small grabenlike features. The basalt is vesicular and contains olivine phenocrysts with minor plagioclase and clinopyroxene set in a holocrystalline groundmass (Table 1). The scoria cones are characterized by poorly to moderately sorted and loose grains ranging from lapilli- to bomb-size and having different shapes (rod, spindle, etc.). The rock fragments in the scoria are mainly olivine to olivine-clinopyroxene phyric basalts and mantle xenoliths. The trachyte forms columnar-jointed upright plugs which intruded the older basalts. The plugs contain coarse- to mediumgrained sanidine with trachytic texture.

\section{GEOCHEMISTRY}

\section{Analytical methods}

Representative samples from all rock types, except for scoria, were crushed into $\mathrm{mm}$-sized chips using a hydraulic crusher; the freshest rock chips carefully handpicked under a stereomicroscope were pulverized with an alumina ceramic swing mill.

The whole-rock major elements and selected trace elements (Co, Cr, V, Ni, Nb, Pb, Rb, Th, Y, Zr, Ba and $\mathrm{Ce}$ ) were determined on the fused glass beads by using $\mathrm{X}$-ray fluorescence spectrometry (Shimadzu XRF-1800) at the Department of Physics and Earth Sciences, University of the Ryukyus (Table 1). The glass beads were prepared by fusing mixtures of $1( \pm 0.0005) \mathrm{g}$ of rock powder and $5( \pm$ $0.0010) \mathrm{g}$ of lithium tetraborate. Calibration curves were constructed using international standard rock samples from the Geological Survey of Japan (GSJ) and US Geological Survey (USGS).

The concentrations of most trace elements, including rare earth elements (REE), were measured by inductively coupled plasma mass spectroscopy (ICP-MS), Yokogawa Analytical Systems (now Agilent Technologies) HP4500, at the University of the Ryukyus (Table 2). Detailed analytical procedures are given in Shinjo et al. (2000). A USGS BCR-2 standard solution was used as calibration standard with ${ }^{115}$ In internal standard. ICP-MS data are used in the figures herein.

Reproducibility and accuracy of the XRF analyses were checked using the international rock standards JB-1 (GSJ), BCR-2 (USGS) and BHVO-2 (USGS), whereas those of the ICP-MS analyses were checked using the international rock standard JA-1 (GSJ). Accuracy for 
Table 2. Trace element contents obtained by ICP-MS of volcanic rocks from the Bure area

\begin{tabular}{|c|c|c|c|c|c|c|c|c|c|c|c|}
\hline \multirow{2}{*}{$\begin{array}{l}\text { Type } \\
\text { Sample no }\end{array}$} & \multicolumn{9}{|c|}{ Transitional tholeiite basalts } & \multicolumn{2}{|c|}{ Alkaline basalts } \\
\hline & $\begin{array}{c}\text { TD- } \\
1228 \mathrm{~A}\end{array}$ & $\begin{array}{c}\text { ASW- } \\
503\end{array}$ & TL-253 & $\begin{array}{l}\text { EH- } \\
235 \mathrm{~A}\end{array}$ & AN-201 & $\begin{array}{c}\text { MH- } \\
4510 \mathrm{~A}\end{array}$ & $\begin{array}{l}\text { MH- } \\
4521\end{array}$ & TD-1202 & TD-1239 & $\begin{array}{c}\text { TD- } \\
1034 \mathrm{~B}\end{array}$ & SM-120 \\
\hline $\mathrm{Sc}(\mathrm{ppm})$ & 43.8 & 36.0 & 38.4 & 42.2 & 31.1 & 40.5 & 28.5 & 37.6 & 28.7 & 20.8 & 12.1 \\
\hline V & 436 & 375 & 340 & 471 & 223 & 498 & 329 & 334 & 203 & 158 & 161 \\
\hline $\mathrm{Cr}$ & 24 & 52 & 33 & 209 & 168 & 22 & 37 & 71 & 456 & 14 & 18 \\
\hline $\mathrm{Co}$ & 55 & 63 & 51 & 70 & 47 & 64 & 34 & 52 & 64 & 45 & 26 \\
\hline $\mathrm{Ni}$ & 34 & 97 & 51 & 171 & 105 & 35 & 19 & 43 & 298 & 13 & 12 \\
\hline $\mathrm{Rb}$ & 18.0 & 15.7 & 8.3 & 8.9 & 4.5 & 41.3 & 19.9 & 9.8 & 13.7 & 34.3 & 53.6 \\
\hline $\mathrm{Sr}$ & 392 & 322 & 335 & 296 & 295 & 439 & 616 & 373 & 351 & 744 & 1,223 \\
\hline $\mathrm{Y}$ & 46.2 & 31.2 & 32.5 & 22.0 & 18.8 & 60.0 & 36.6 & 39.4 & 26.3 & 49.9 & 32.0 \\
\hline $\mathrm{Zr}$ & 211 & 165 & 155 & 126 & 70 & 305 & 161 & 157 & 83 & 323 & 217 \\
\hline $\mathrm{Nb}$ & 11.2 & 10.3 & 14.6 & 12.2 & 4.0 & 23.3 & 20.7 & 8.6 & 19.8 & 48.5 & 71.5 \\
\hline Cs & 0.19 & 0.33 & 0.06 & 0.06 & 0.02 & 0.38 & 0.33 & 0.10 & 0.10 & 0.15 & 0.44 \\
\hline $\mathrm{Ba}$ & 133 & 343 & 89 & 243 & 653 & 279 & 733 & 150 & 242 & 597 & 1,007 \\
\hline Hf & 5.04 & 4.51 & 3.91 & 3.61 & 1.79 & 7.37 & 4.04 & 3.86 & 2.09 & 6.89 & 4.84 \\
\hline $\mathrm{Ta}$ & 0.65 & 0.59 & 0.83 & 0.73 & 0.22 & 1.39 & 1.18 & 0.46 & 1.12 & 2.44 & 3.99 \\
\hline $\mathrm{Pb}$ & 2.82 & 4.77 & 1.59 & 2.52 & 0.71 & 3.45 & 3.19 & 2.04 & 1.06 & 4.54 & 5.25 \\
\hline Th & 1.32 & 1.94 & 1.08 & 1.72 & 0.31 & 2.65 & 2.09 & 1.03 & 1.42 & 2.81 & 5.58 \\
\hline $\mathrm{U}$ & 0.51 & 0.71 & 0.31 & 0.44 & 0.10 & 0.72 & 0.67 & 0.47 & 0.37 & 0.70 & 1.43 \\
\hline $\mathrm{La}$ & 11.16 & 20.09 & 10.31 & 17.50 & 4.70 & 28.33 & 25.59 & 8.91 & 14.39 & 30.33 & 60.68 \\
\hline $\mathrm{Ce}$ & 28.21 & 48.53 & 25.49 & 43.14 & 11.94 & 68.14 & 62.39 & 21.66 & 24.66 & 66.74 & 121.20 \\
\hline $\operatorname{Pr}$ & 4.31 & 6.70 & 3.60 & 5.93 & 1.83 & 9.41 & 8.99 & 3.17 & 3.15 & 8.76 & 14.21 \\
\hline $\mathrm{Nd}$ & 20.11 & 30.14 & 16.55 & 26.63 & 8.58 & 42.09 & 41.54 & 14.78 & 13.35 & 36.07 & 54.26 \\
\hline $\mathrm{Sm}$ & 6.21 & 8.05 & 4.86 & 7.01 & 2.60 & 11.56 & 9.71 & 4.67 & 3.01 & 8.78 & 10.13 \\
\hline $\mathrm{Eu}$ & 2.17 & 2.56 & 1.69 & 2.36 & 1.03 & 3.63 & 3.72 & 1.75 & 1.20 & 2.99 & 3.15 \\
\hline $\mathrm{Gd}$ & 7.38 & 8.04 & 5.62 & 6.76 & 3.06 & 13.23 & 9.50 & 6.04 & 3.87 & 9.35 & 8.97 \\
\hline $\mathrm{Tb}$ & 1.27 & 1.29 & 0.92 & 1.07 & 0.54 & 2.12 & 1.32 & 1.05 & 0.64 & 1.43 & 1.21 \\
\hline Dy & 7.70 & 6.99 & 5.69 & 5.66 & 3.32 & 12.58 & 7.14 & 6.44 & 4.10 & 8.25 & 6.58 \\
\hline Ho & 1.58 & 1.39 & 1.13 & 1.07 & 0.71 & 2.48 & 1.36 & 1.31 & 0.87 & 1.66 & 1.29 \\
\hline $\mathrm{Er}$ & 4.19 & 3.63 & 2.96 & 2.72 & 1.93 & 6.41 & 3.39 & 3.50 & 2.46 & 4.35 & 3.38 \\
\hline $\mathrm{Tm}$ & 0.62 & 0.51 & 0.44 & 0.37 & 0.29 & 0.88 & 0.46 & 0.51 & 0.35 & 0.64 & 0.48 \\
\hline $\mathrm{Yb}$ & 3.96 & 3.16 & 2.75 & 2.21 & 1.83 & 5.12 & 2.87 & 3.30 & 2.17 & 4.17 & 3.00 \\
\hline $\mathrm{Lu}$ & 0.55 & 0.45 & 0.39 & 0.31 & 0.27 & 0.70 & 0.40 & 0.45 & 0.32 & 0.60 & 0.43 \\
\hline
\end{tabular}

major and trace elements is mostly better than $3 \%$ and $10 \%$, respectively.

$\mathrm{Sr}, \mathrm{Nd}$ and $\mathrm{Pb}$ isotope analyses were undertaken on handpicked rock chips ( $\leq 1 \mathrm{~mm}$ ) using a Finnigan MAT262 mass spectrometer at the University of the Ryukyus (Table 3). Representative samples were chosen to cover the entire compositional range. Rock chips with visible phenocrysts were rejected. $\mathrm{Sr}, \mathrm{Nd}$ and $\mathrm{Pb}$ were extracted from the same solution through a combination of ion-exchange columns. Further analytical procedures are described in Shinjo et al. (2000). The isotopic ratios were corrected for mass fractionation by normalizing to ${ }^{86} \mathrm{Sr} /{ }^{88} \mathrm{Sr}=0.1194$ and ${ }^{146} \mathrm{Nd} /{ }^{144} \mathrm{Nd}=0.7219$. During this study, the SRM987 Sr standard gave a mean ${ }^{87} \mathrm{Sr} /{ }^{86} \mathrm{Sr}=$ $0.710239 \pm 0.000026(2 \mathrm{SD} ; \mathrm{n}=5)$ and the Nd standard La Jolla gave a mean ${ }^{143} \mathrm{Nd} /{ }^{144} \mathrm{Nd}=0.511831 \pm 0.000019$ (2SD; $\mathrm{n}=5$ ). The ${ }^{204} \mathrm{~Pb}^{-207} \mathrm{~Pb}$ double spike method was applied to $\mathrm{Pb}$ isotopic analyses. Fractionation-corrected values for SRM981 $\mathrm{Pb}$ standard $(\mathrm{n}=5)$ were ${ }^{206} \mathrm{~Pb} /{ }^{204} \mathrm{~Pb}=$ $16.9411 \pm 0.0021(2 \mathrm{SD}),{ }^{207} \mathrm{~Pb} /{ }^{204} \mathrm{~Pb}=15.4983 \pm 0.0016$ (2SD) and ${ }^{208} \mathrm{~Pb} /{ }^{204} \mathrm{~Pb}=36.7208 \pm 0.0039$ (2SD), which agree well with the preferred values from Thirlwall (2000). 
Table 2. (Continued)

\begin{tabular}{|c|c|c|c|c|c|c|c|c|c|c|}
\hline \multirow{2}{*}{$\begin{array}{l}\text { Type } \\
\text { Sample no }\end{array}$} & \multicolumn{6}{|c|}{ Alkaline basalts } & \multicolumn{2}{|c|}{ Quat. basalts } & \multicolumn{2}{|c|}{ Trachyte plugs } \\
\hline & $\begin{array}{l}\text { SOG- } \\
3061 \mathrm{~B}\end{array}$ & $\begin{array}{l}\text { SOG- } \\
3104\end{array}$ & $\begin{array}{l}\text { SOG- } \\
3091\end{array}$ & $\begin{array}{l}\text { SOG- } \\
3005\end{array}$ & $\begin{array}{l}\text { SOG- } \\
3043\end{array}$ & SM-172 & TD-1003 & $\begin{array}{l}\text { SOG- } \\
3157\end{array}$ & $\begin{array}{c}\text { TD- } \\
1136 A 2\end{array}$ & SM-113 \\
\hline $\mathrm{Sc}(\mathrm{ppm})$ & 2.9 & 2.6 & 15.3 & 38.6 & 28.4 & 24.0 & 26.7 & 27.9 & 4.0 & 4.6 \\
\hline V & 16 & 6 & 143 & 337 & 233 & 144 & 223 & 195 & 3 & 4 \\
\hline $\mathrm{Cr}$ & 16 & 8 & 18 & 711 & 225 & 21 & 165 & 92 & 12 & 9 \\
\hline Co & - & _ & 38 & 73 & 54 & 40 & 50 & 40 & - & - \\
\hline $\mathrm{Ni}$ & _ & _ & 14 & 318 & 210 & 22 & 141 & 49 & - & - \\
\hline $\mathrm{Rb}$ & 138 & 108 & 66.2 & 21.8 & 49.9 & 16.1 & 20.9 & 17.9 & 219 & 205 \\
\hline $\mathrm{Sr}$ & 1,548 & 216 & 948 & 503 & 792 & 550 & 452 & 519 & 10 & 12 \\
\hline $\mathrm{Y}$ & 45.4 & 27.2 & 35.7 & 23.1 & 24.1 & 34.5 & 17.7 & 22.2 & 122 & 52 \\
\hline $\mathrm{Zr}$ & 472 & 379 & 308 & 155 & 155 & 176 & 107 & 127 & 1,251 & 1,064 \\
\hline $\mathrm{Nb}$ & 168.0 & 152.5 & 83.3 & 32.9 & 79.9 & 30.6 & 29.7 & 30.8 & 175.8 & 347 \\
\hline Cs & 0.81 & 0.27 & 0.47 & 0.38 & 0.53 & 0.10 & 0.25 & 0.21 & 0.17 & 0.82 \\
\hline $\mathrm{Ba}$ & 1,690 & 974 & 580 & 361 & 643 & 403 & 341 & 322 & 194 & 34 \\
\hline Hf & 8.78 & 8.57 & 6.94 & 3.71 & 3.55 & 4.35 & 2.62 & 3.05 & 32.2 & 24.3 \\
\hline $\mathrm{Ta}$ & 8.38 & 8.02 & 4.51 & 1.94 & 4.28 & 1.78 & 1.66 & 1.68 & 9.17 & 18.92 \\
\hline $\mathrm{Pb}$ & 9.27 & 10.20 & 4.28 & 2.45 & 3.19 & 1.98 & 2.01 & 2.12 & 14.3 & 26.3 \\
\hline Th & 9.14 & 13.16 & 6.06 & 2.24 & 5.99 & 1.44 & 2.27 & 1.89 & 11.0 & 30.0 \\
\hline $\mathrm{U}$ & 2.39 & 3.34 & 1.50 & 0.60 & 1.37 & 0.37 & 0.52 & 0.48 & 2.61 & 6.32 \\
\hline $\mathrm{La}$ & 75.51 & 106.50 & 46.67 & 21.97 & 43.98 & 20.84 & 19.53 & 17.83 & 135 & 144 \\
\hline $\mathrm{Ce}$ & 139.10 & 190.10 & 98.38 & 46.17 & 81.32 & 48.38 & 39.68 & 36.91 & 301 & 244 \\
\hline $\operatorname{Pr}$ & 15.45 & 19.01 & 11.90 & 5.80 & 9.08 & 6.33 & 4.70 & 4.48 & 34.86 & 23.86 \\
\hline $\mathrm{Nd}$ & 53.64 & 59.13 & 46.62 & 24.35 & 33.70 & 27.39 & 18.48 & 18.18 & 127.20 & 71.04 \\
\hline $\mathrm{Sm}$ & 9.24 & 8.88 & 10.11 & 5.88 & 6.59 & 6.80 & 4.12 & 4.18 & 27.04 & 11.51 \\
\hline $\mathrm{Eu}$ & 3.21 & 2.03 & 3.31 & 1.96 & 2.12 & 2.22 & 1.38 & 1.47 & 2.73 & 1.50 \\
\hline $\mathrm{Gd}$ & 8.58 & 6.92 & 9.29 & 6.06 & 6.17 & 7.06 & 4.00 & 4.34 & 25.14 & 9.65 \\
\hline $\mathrm{Tb}$ & 1.21 & 0.98 & 1.31 & 0.91 & 0.87 & 1.06 & 0.59 & 0.68 & 4.16 & 1.43 \\
\hline Dy & 6.89 & 5.33 & 7.06 & 5.09 & 4.91 & 6.17 & 3.35 & 4.02 & 25.41 & 8.62 \\
\hline Ho & 1.42 & 1.13 & 1.34 & 0.98 & 0.96 & 1.26 & 0.66 & 0.81 & 5.19 & 1.83 \\
\hline Er & 4.07 & 3.26 & 3.31 & 2.52 & 2.52 & 3.44 & 1.83 & 2.14 & 14.69 & 5.62 \\
\hline $\mathrm{Tm}$ & 0.65 & 0.52 & 0.47 & 0.34 & 0.35 & 0.47 & 0.25 & 0.31 & 2.30 & 0.92 \\
\hline $\mathrm{Yb}$ & 4.36 & 3.55 & 2.95 & 2.00 & 2.19 & 3.17 & 1.66 & 2.03 & 14.59 & 7.03 \\
\hline $\mathrm{Lu}$ & 0.66 & 0.56 & 0.41 & 0.27 & 0.32 & 0.45 & 0.23 & 0.28 & 2.10 & 1.05 \\
\hline
\end{tabular}

\section{Major element data}

In total-alkali vs. silica and CIPW normative diagrams, the Bure volcanic rocks define two chemically distinct suites (Fig. 2). One suite includes ne-ol alkaline CFBs, the Quaternary basalts and the trachyte plugs, whereas the hy-qt transitional tholeiitic CFBs define the other suite. The alkaline CFBs vary from basanite, basalt, trachybasalt to basaltic trachyandesite. A few alkaline CFBs exhibit the evolved trachytic composition observed in samples from the trachyte plugs. The transitional tholeiitic CFBs are generally basalts; only one sample has a basaltic trachyandesitic composition. Both the alkaline and tholeiitic rocks exhibit a wide range of $\mathrm{Mg \#} \mathrm{(70-25}$ and 68-35, respectively).

Major element variations relative to $\mathrm{MgO}(\mathrm{wt} \%)$ are shown in Figure 3. MgO contents vary from $0.05 \mathrm{wt} \%$ in the trachyte to $12 \mathrm{wt} \%$ in the alkaline basalts, but most of the analyzed rocks contain < 6 wt $\% \mathrm{MgO}$. Negative trends are observed for $\mathrm{SiO}_{2}, \mathrm{~K}_{2} \mathrm{O}$ and $\mathrm{Na}_{2} \mathrm{O}$ (Fig. 3). $\mathrm{TiO}_{2}$ is very variable and only a few Bure basalts fall into the field of low-Ti type basalts defined by Pik et al. (1998, 1999). $\mathrm{CaO}$ and $\mathrm{Fe}_{2} \mathrm{O}_{3}$ are almost constant in the Bure volcanic rocks with $\mathrm{MgO}>6 \mathrm{wt} \%$, whereas both define positive trends for rocks with lower $\mathrm{MgO}$ values, although the trend was not so well defined for $\mathrm{Fe}_{2} \mathrm{O}_{3}$ (Fig. 3). $\mathrm{Al}_{2} \mathrm{O}_{3}$ 
Table 3. Isotopic data for the Bure volcanic rocks

\begin{tabular}{lcccccccc}
\hline Samples & ${ }^{87} \mathrm{Sr} /{ }^{86} \mathrm{Sr}$ & $2 \mathrm{SE}$ & ${ }^{143} \mathrm{Nd} /{ }^{144} \mathrm{Nd}$ & $2 \mathrm{SE}$ & $\varepsilon_{\mathrm{Nd}}$ & ${ }^{206} \mathrm{~Pb} /{ }^{204} \mathrm{~Pb}$ & ${ }^{207} \mathrm{~Pb} /{ }^{204} \mathrm{~Pb}$ & ${ }^{208} \mathrm{~Pb} /{ }^{204} \mathrm{~Pb}$ \\
\hline Trachyte plugs & & & & & & & & \\
TD-1136A2 & 0.737730 & 21 & 0.512838 & 10 & 3.90 & 18.3657 & 15.5420 & 37.9524 \\
SM-113 & 0.721525 & 25 & 0.512763 & 13 & 2.44 & 19.4506 & 15.6413 & 39.2440 \\
\hline Quat. basalts (Alkaline) & & & & & & & \\
TD-1003 & 0.703569 & 20 & 0.512850 & 8 & 4.14 & 18.9140 & 15.5823 & 38.6000 \\
SOG-3157 & 0.703627 & 16 & 0.512850 & 12 & 4.14 & 18.9286 & 15.5905 & 38.6360 \\
\hline Alkaline basalts & & & & & & & & \\
TD-1034B & 0.703407 & 17 & 0.512828 & 10 & 3.54 & 18.6354 & 15.6224 & 38.5295 \\
SM-120 & 0.703379 & 17 & 0.512794 & 9 & 3.09 & 19.5763 & 15.6484 & 39.2853 \\
SOG-3091 & 0.703548 & 16 & 0.512815 & 8 & 3.45 & 19.4503 & 15.6774 & 39.4226 \\
SOG-3005 & 0.703279 & 13 & 0.512870 & 10 & 3.95 & 19.8325 & 15.6632 & 39.6138 \\
SOG-3043 & 0.703145 & 15 & 0.512880 & 12 & 4.37 & 19.6072 & 15.6415 & 39.2357 \\
SM-172 & 0.703232 & 17 & 0.512873 & 9 & 4.52 & 18.4220 & 15.5451 & 38.0134 \\
\hline Transitional tholeiite basalts & & & & & & & \\
TD-1228A & 0.703774 & 18 & 0.512990 & 11 & 6.48 & 18.5630 & 15.5320 & 37.9504 \\
TD-1239 & 0.703285 & 15 & 0.512886 & 14 & 4.74 & 19.0791 & 15.5948 & 38.8454 \\
ASW-503 & 0.704293 & 15 & 0.512829 & 9 & 3.48 & 18.8396 & 15.5707 & 38.1825 \\
TL-253 & 0.703447 & 19 & 0.513041 & 9 & 7.52 & 18.3556 & 15.4959 & 38.1313 \\
EH-235A & 0.703949 & 15 & 0.513034 & 10 & 7.50 & 18.4713 & 15.5220 & 38.1647 \\
AN-201 & 0.703314 & 16 & 0.512807 & 11 & 2.93 & 18.6321 & 15.5648 & 38.1002 \\
MH-4510A & 0.703843 & 19 & 0.512979 & 9 & 6.39 & 18.4310 & 15.5196 & 38.2754 \\
MH-4521 & 0.704279 & 16 & 0.512862 & 10 & 4.24 & 18.8497 & 15.5874 & 38.4454 \\
TD-1202 & 0.704105 & 16 & 0.512905 & 9 & 4.80 & 18.7528 & 15.5556 & 38.1209 \\
\hline
\end{tabular}

2SE (standard error) corresponds to last two digits. For $\varepsilon N d$ calculations, $t$ is assumed as $27 \mathrm{Ma}$ for transitional tholeiite basalts and alkaline basalts, 0 Ma for Quaternary basalts and trachyte plugs. CHUR value for Nd is 0.512638 .

is negatively correlated with $\mathrm{MgO}$ within the alkaline rocks, whereas it is scattered and displays lower values in the transitional tholeiite basalts. $\mathrm{CaO} / \mathrm{Al}_{2} \mathrm{O}_{3}$ ratios are relatively constant in transitional tholeiite basalt (0.6-0.8), which implies that olivine fractionation was predominant and plagioclase was not an important phase during fractionation.

\section{Trace element data}

The variations of the two suites are also well expressed in $\mathrm{MgO}$ against some trace element diagrams (Fig. 4). The decreases in $\mathrm{Cr}$ and $\mathrm{Ni}$ reflect early fractionation of olivine in both alkaline and transitional tholeiite rocks, whereas a positive trend for $\mathrm{V}$ was observed among the alkaline rocks only, which suggests that clinopyroxene fractionation affected these rocks. The incompatible elements ( $\mathrm{Nb}, \mathrm{Zr}, \mathrm{Rb}$ and $\mathrm{Y}$ ) define negative trends, although with some dispersion, from basaltic to felsic compositions. $\mathrm{Ba}$ and $\mathrm{Sr}$ are very variable among the Bure volcanic rocks with $\mathrm{MgO}>4$ wt\% and reach low values in the most evolved trachytic samples, which indicate that an alkali feldspar fractionation affected these rocks.

The chondrite-normalized rare-earth element (REE) patterns are given in Figure 5. Light REE (LREE) enrichment relative to heavy REE (HREE) is stronger in alkaline rocks than in tholeiites. A negative Eu anomaly $\left(\mathrm{Eu} / \mathrm{Eu}^{*}=0.3-0.7\right)$ is present in the evolved trachytes, which indicates that plagioclase fractionation played a significant role in their genesis.

Primitive mantle-normalized incompatible element diagrams of the representative samples are shown in Figure 6. The transitional tholeiite basalts have flat patterns with slightly negative $\mathrm{Th}$ and $\mathrm{Nb}-\mathrm{Ta}$ anomalies and positive $\mathrm{Ba}$ and $\mathrm{Pb}$ spikes. The alkaline basalts show ocean island basalt (OIB)-like patterns enriched in both large ion lithophile (LILE) and high field strength (HFSE) elements with $\mathrm{Nb}-\mathrm{Ta}$ peak. The alkaline basalts show weak $\mathrm{Ba}$ and $\mathrm{Pb}$ positive spikes and a Th- $\mathrm{U}$ trough. Trachyte plugs have irregular patterns enriched in LILE with pronounced negative anomalies in $\mathrm{Ba}, \mathrm{Sr}, \mathrm{P}$ and $\mathrm{Ti}$, which is indicative of extensive fractionation of feldspar, apatite and $\mathrm{Fe}$-Ti oxides. 


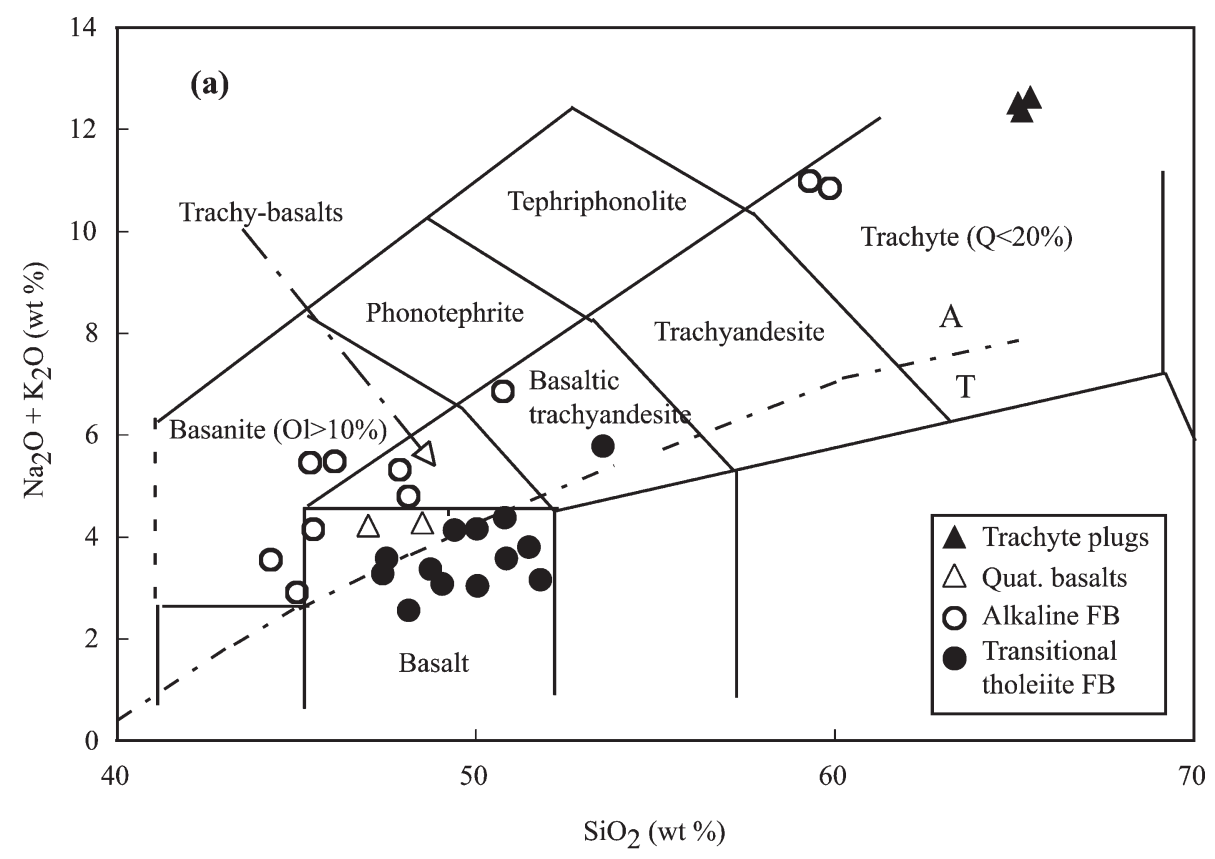

(b)

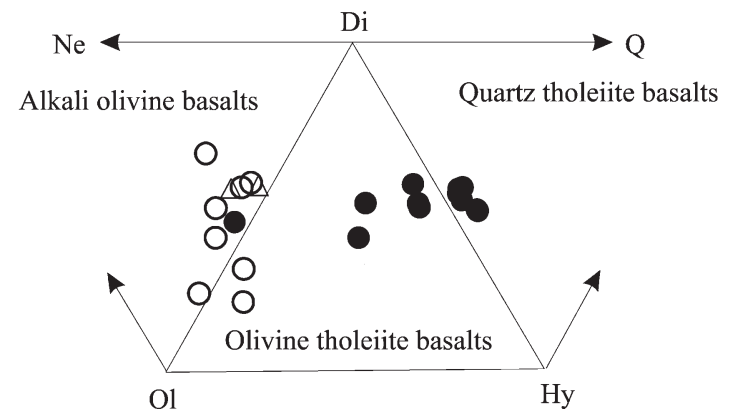

Figure 2. (a) Total-alkali vs. silica diagram for the Bure volcanic rocks (Le Maitre et al., 1989). The Tholeiitic (T)-Alkaline (A) divide is shown (Irving and Baragar, 1971). (b) CIPW-normative composition diagram for the Bure volcanic rocks (Thompson et al., 1983). FB, flood basalts.

\section{$\mathrm{Sr}-\mathrm{Nd}-\mathrm{Pb}$ isotope data}

The $\mathrm{Sr}, \mathrm{Nd}$ and $\mathrm{Pb}$ isotope compositions of representative samples of tholeiitic and alkaline rock types are shown in Table 4 and plotted in Figures 7 and 8. Also plotted are the isotopic compositions of Arabian lithospheric mantle and basalts from the Afar, Gulf of Aden, Djibouti, southern Ethiopia and northwestern Ethiopia. Most of the transitional tholeiite basalts from the Bure area are displaced to higher ${ }^{87} \mathrm{Sr} /{ }^{86} \mathrm{Sr}(0.70329-0.70429)$ and ${ }^{143} \mathrm{Nd} /{ }^{144} \mathrm{Nd}$ (0.51281-0.51304), and plot in a region generally separate from the alkaline samples $\left({ }^{87} \mathrm{Sr} /{ }^{86} \mathrm{Sr}=0.70315^{-}\right.$ 0.70363 and ${ }^{143} \mathrm{Nd} /{ }^{144} \mathrm{Nd}=0.51279-0.51288$ ). Moreover, the trends defined by these two types of rock are different (Fig. 7a). Indeed, tholeiitic rocks extend between the depleted (DM) and enriched (EMI) mantle end-members, whereas the alkaline rocks extend from the HIMU endmember towards enriched (EMI) mantle. The transitional tholeiite basalts mostly overlap the HT1 basalts of Pik et al. (1999) and fall in the intermediate position between
Djibouti and Afar and Gulf of Aden basalts. The alkaline basalts fall within the field of LT basalts with lower ${ }^{87} \mathrm{Sr} /{ }^{86} \mathrm{Sr}$ and ${ }^{143} \mathrm{Nd} /{ }^{144} \mathrm{Nd}$ and partially overlap the field of northern transect basalts from southern Ethiopia (Fig. 7b).

The $\mathrm{Pb}$ isotopic compositions of the Bure volcanic rocks cover the relatively wide range already observed for the northern transect basalts of southern Ethiopia and define a trend subparallel to the Northern Hemisphere Reference Line (NHRL) of Hart (1984) in $\mathrm{Pb}-\mathrm{Pb}$ diagrams (Fig. 8a, b). In detail, most of the alkaline CFBs have more radiogenic $\mathrm{Pb}$ isotopic composition than the tholeiites and Quaternary basalts, which plot toward the HIMU field $\left({ }^{206} \mathrm{~Pb} /{ }^{204} \mathrm{~Pb}=19.45-19.83,{ }^{207} \mathrm{~Pb} /{ }^{204} \mathrm{~Pb}=\right.$ $15.65-15.68$ and ${ }^{208} \mathrm{~Pb} /{ }^{204} \mathrm{~Pb}=39.24-39.61$ ). The Quaternary basalts are closer to the HT2-type basalts ${ }^{206} \mathrm{~Pb} /$ ${ }^{204} \mathrm{~Pb}=18.91-18.93,{ }^{207} \mathrm{~Pb} /{ }^{204} \mathrm{~Pb}=15.58-15.59$ and ${ }^{208} \mathrm{~Pb} /$ $\left.{ }^{204} \mathrm{~Pb}=38.60-38.64\right)$, whereas the transitional tholeiite CFBs and the two Oligocene alkaline CFB samples have lower $\mathrm{Pb}$ isotopic ratios spread towards the $\mathrm{DM}$ field ${ }^{206} \mathrm{~Pb} /{ }^{204} \mathrm{~Pb}=18.36-19.08,{ }^{207} \mathrm{~Pb} /{ }^{204} \mathrm{~Pb}=15.50-15.59$ and ${ }^{208} \mathrm{~Pb} /$ 

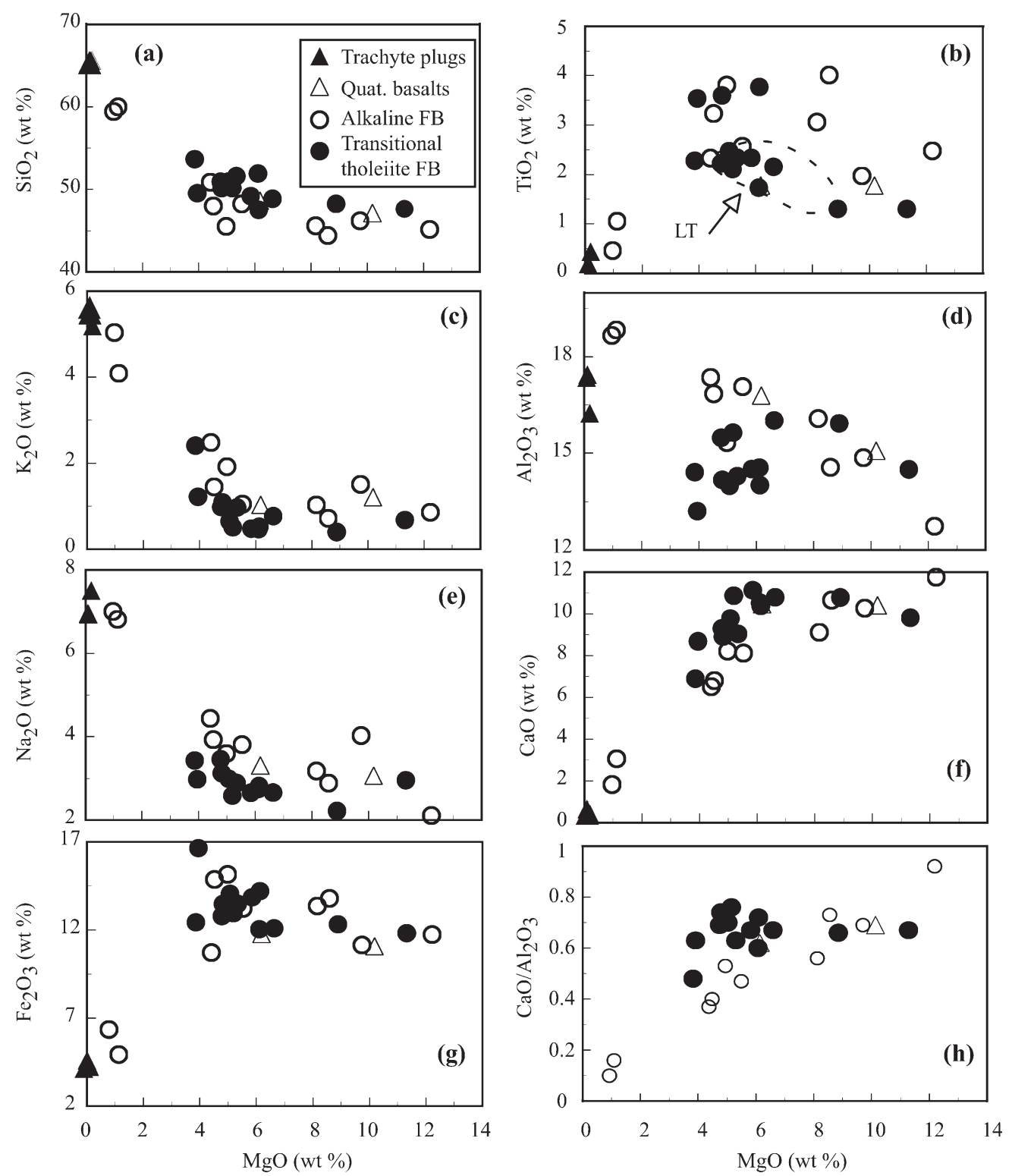

Figure 3. Major element vs. $\mathrm{MgO}(\mathrm{wt} \%)$ diagram for Bure volcanic rocks. The dashed line in the $\mathrm{TiO}_{2}{ }^{-}$ $\mathrm{MgO}$ plot (b) indicates the field of the NW Ethiopian Low-Ti (LT) magma type flood basalts (Pik et al., 1998, 1999).

$\left.{ }^{204} \mathrm{~Pb}=37.95-38.85\right)$. The two analyzed trachyte samples display very different $\mathrm{Pb}$ isotopic compositions and plot at the ends of the field of the Bure samples.

\section{DISCUSSION}

\section{Crustal contamination process}

The variation of major, incompatible trace elements and $\mathrm{Sr}-\mathrm{Nd}-\mathrm{Pb}$ isotopic ratios within the Bure volcanic rocks might reflect either the contribution of different mantle sources or a crustal component in their petrogenesis (Figs. 2-8).

The transitional tholeiite CFBs have wide variability of incompatible trace element ratios, strong enrichment of $\mathrm{Ba}$ and $\mathrm{Pb}$ with depleted HFSE (Th, Nb and Ta) (Fig. 6) and variable ${ }^{87} \mathrm{Sr} /{ }^{86} \mathrm{Sr},{ }^{143} \mathrm{Nd} /{ }^{144} \mathrm{Nd}$ (Fig. 7) and unradiogenic ${ }^{206} \mathrm{~Pb} /{ }^{204} \mathrm{~Pb}$ (Fig. 8). These variations cannot be explained by simple fractional crystallization and partial melting of common sources but require variations in both source compositions and melting conditions.

Moreover, the fact that the Bure volcanic rocks passed through the continental crust raises the possibility that crustal contamination produced some of their isotopic and geochemical signatures. Indeed, the negative $\mathrm{MgO}$ vs ${ }^{87} \mathrm{Sr} /{ }^{86} \mathrm{Sr}$ correlation and the large range of ${ }^{87} \mathrm{Sr} /{ }^{86} \mathrm{Sr}$ (Fig. 9a) suggest that the transitional tholeiite basalts were subject to crustal contamination and might have experienced an assimilation-fractional crystallization (AFC) process (DePaolo, 1981). Other evidence in favor of crustal contamination is shown in Figure 9 (b, c), where the transitional tholeiite basalts tend to show a positive correlation 

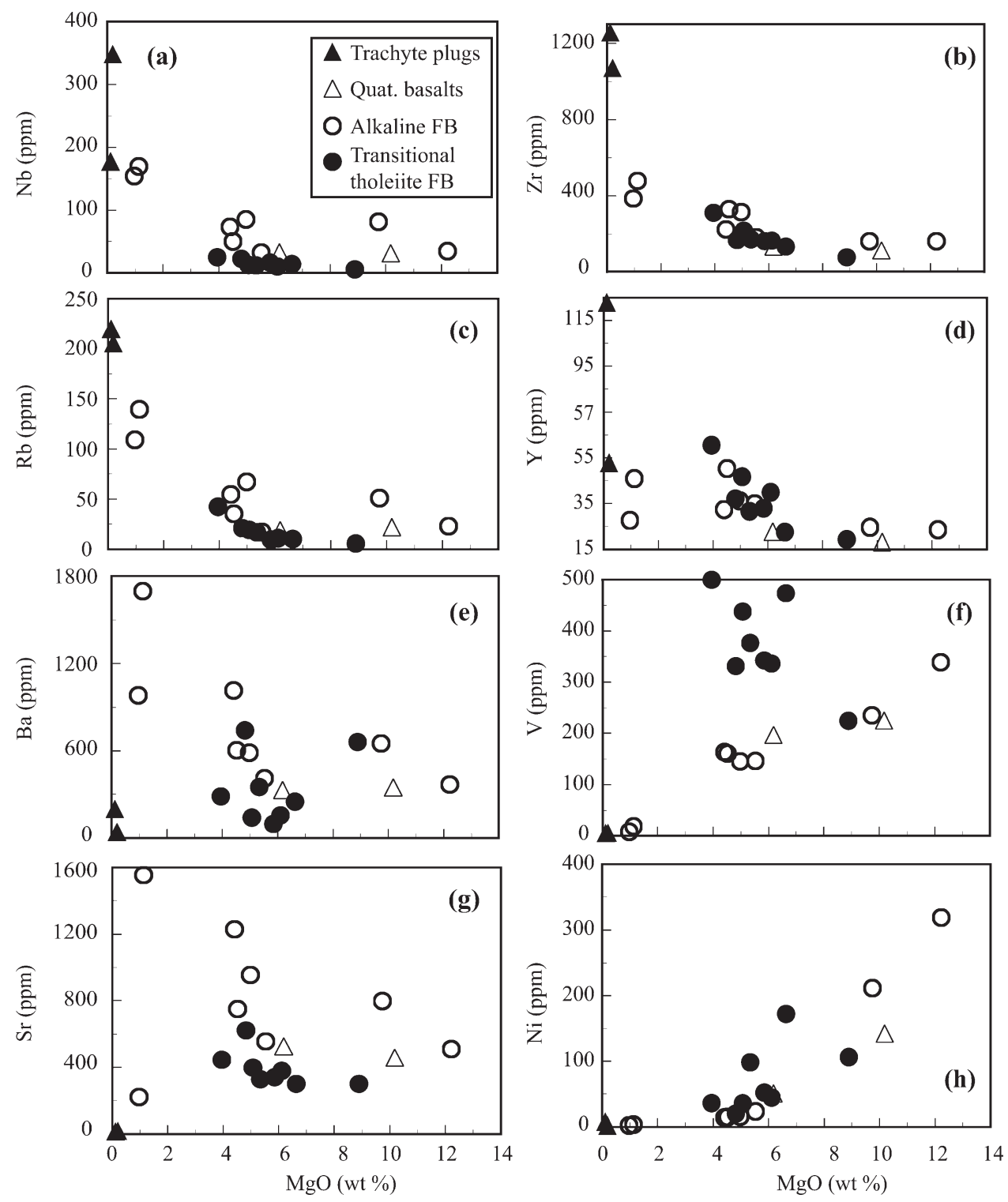

Figure 4. Trace element content vs. $\mathrm{MgO}$ (wt\%) diagram for the Bure volcanic rocks.

of $\mathrm{Rb} / \mathrm{Nb}$ with $\mathrm{Rb}$ and a negative correlation of $\mathrm{Ba} / \mathrm{Nb}$ with ${ }^{143} \mathrm{Nd} /{ }^{144} \mathrm{Nd}$. The alkalis are strongly enriched in felsic crustal rocks with comparable or lower $\mathrm{Nb}$ compared with the basalts, and so even small degrees of contamination would cause strong enrichment in alkali element concentrations and lead to high alkali/ $\mathrm{Nb}$ ratios in crustally contaminated basalts.

To test such a contamination process, we carried out simple mixing model using sample TL-253 as the basaltic end-member, because this sample has low $\mathrm{Rb} / \mathrm{Nb}, \mathrm{Ba} / \mathrm{Nb}$ and ${ }^{87} \mathrm{Sr} /{ }^{86} \mathrm{Sr}$ and high ${ }^{143} \mathrm{Nd} /{ }^{144} \mathrm{Nd}$ without $\mathrm{K}, \mathrm{Rb}$ and $\mathrm{Ba}$ spikes in the trace element spectra (Fig. 6). The compositions of samples X139 and X37 (Davidson and Wilson, 1989) were chosen as representative of the Pan-African upper crust (UC) and lower crust (LC), respectively. Bulk mixing curves between basalts TL-253 and UC/LC in Figure 9d indicate that, except for one sample, 10\%-20\% of dominantly upper crust is required to explain the crustal contamination signature of transitional tholeiite basalts. A similar proportion of the upper crust in the mixture can also account for the ${ }^{143} \mathrm{Nd} /{ }^{144} \mathrm{Nd}$ (Fig. 9c) of the contaminated basalts. However, such a mixing calculation failed to explain the variation in ${ }^{87} \mathrm{Sr} /{ }^{86} \mathrm{Sr}$ and $\mathrm{Ba} / \mathrm{Nb}$ (Fig. 9e). Bulk mixing calculations in the $\mathrm{Sr}$ isotopic system require a very low amount of UC (up to 5\%), which suggests that the mixing process was not one of bulk contamination. Such a discrepancy could also be due to highly variable Pan-African crustal composition.

In summary, geochemical variation observed in the transitional tholeiite basalts can be accounted for by crustal contamination. In contrast, the uniform incompatible trace element ratios for the alkaline basalt suite, with a limited range of ${ }^{87} \mathrm{Sr} /{ }^{86} \mathrm{Sr}$ and ${ }^{143} \mathrm{Nd} /{ }^{144} \mathrm{Nd}$ but a wide range of ${ }^{206} \mathrm{~Pb} /{ }^{204} \mathrm{~Pb}$ (Figs. 7-9), indicate that fractional crystalli- 


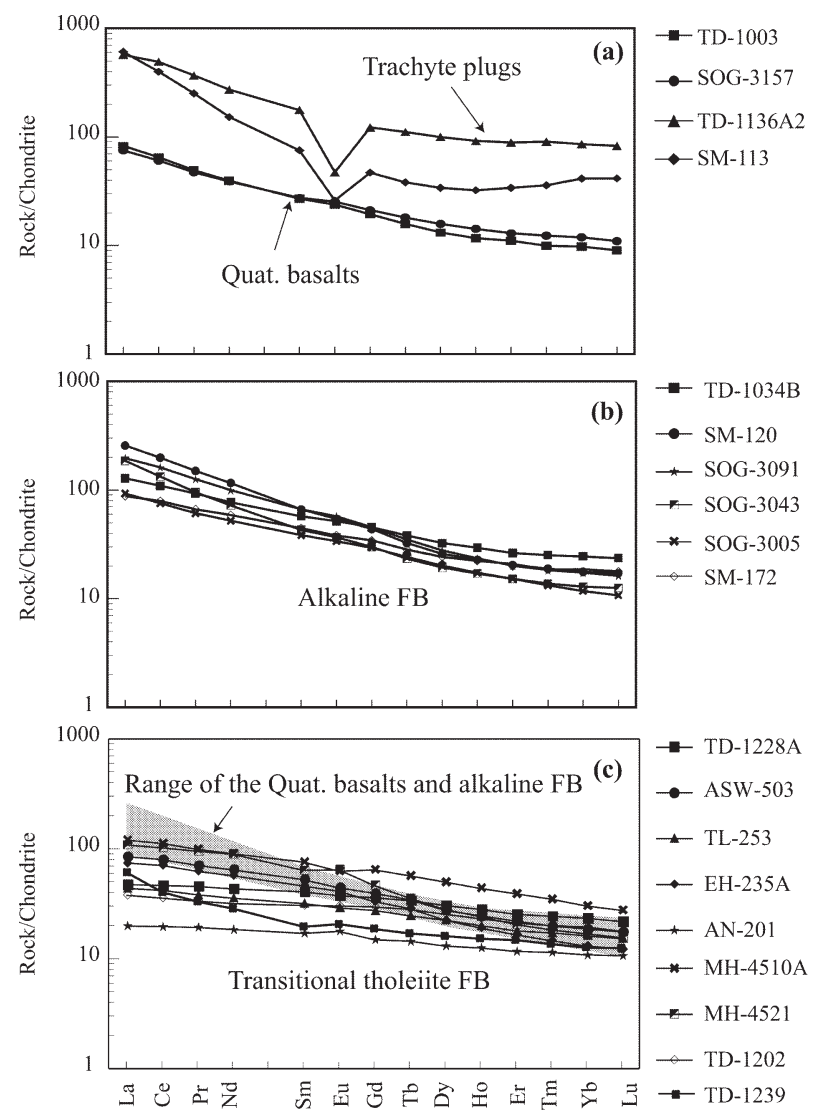

Figure 5. Chondrite-normalized REE patterns for representative Bure volcanic rocks. Chondrite values are taken from Sun and McDonough, 1989. (a) for Quaternary basalts, (b) for alkaline flood basalts and (c) for transitional tholeiite flood basalts. The shaded field shows the range of Quaternary and alkaline flood basalts.

zation of the primary magma from the OIB-like Afar plume was the dominant process for within-group variations in the alkaline basalts (Meshesha and Shinjo, 2004). The alkaline basalts resemble uncontaminated OIB-like Afar plume compositions of the northern transect syn- to post-rift basalts of southern Ethiopia (Stewart and Rogers, 1996), the younger basalts of Djibouti (Deniel et al., 1994) and HT2-type basalts (Pik et al., 1999). It is most important to note that the "presumed" least-contaminated transitional basalt (TL-253) cannot have been formed by the mixing of the alkaline magma with crustal components (Fig. 9c).

\section{Partial melting and magma segregation depth}

The compositional differences between alkaline basalts and least contaminated transitional tholeiite basalts are probably related to different depths and degrees of melting of the deeper asthenospheric mantle. For example, the differences in alkaline contents and degrees of silica satu-
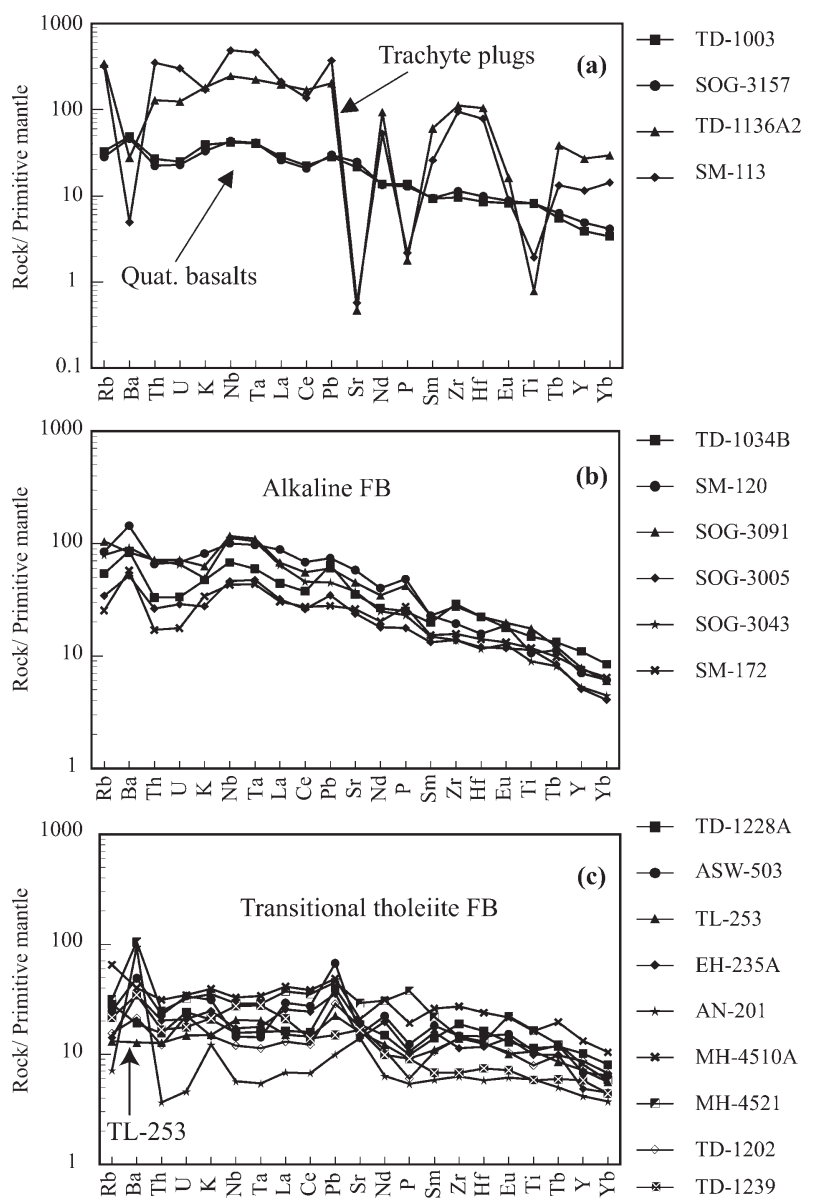

Figure 6. Primitive mantle-normalized multielement patterns for representative Bure volcanic rocks. Primitive mantle values are from Sun and McDonough, 1989. (a) for Quaternary basalts and trachyte plugs, (b) for alkaline flood basalts and (c) for transitional tholeiite flood basalts.

ration between the two suites (Fig. 2) could reflect such different depths of melting (e.g., Kushiro, 1994). It is well known that small degrees of partial melting at high pressure produce magma with normative nepheline, whereas a large degree of melting at lower pressure produces magma with normative hypersthene and quartz (DePaolo and Daley, 2000).

Compositions of the most primitive basalts amongst Bure basalts were plotted onto the olivine-plagioclasequartz plane from the diopside apex (Fig. 9f; Walker et al., 1979) with partial melt compositions obtained in peridotite melting experiments at various pressures (Hirose and Kushiro, 1993). These basalts plot close to the melt compositions found at pressures between $\sim 2.5$ and $3 \mathrm{GPa}$ (i.e., depths greater than $70 \mathrm{~km}$ ). This suggests that the melt was produced in the presence of garnet. In addition, chondrite-normalized $\mathrm{Tb} / \mathrm{Yb}$ (or $\mathrm{Dy} / \mathrm{Yb}$ ) ratios are almost similar for both the alkaline $\left((\mathrm{Tb} / \mathrm{Yb})_{\mathrm{N}}=1.3-2.1\right.$ and $\left.(\mathrm{Dy} / \mathrm{Yb})_{\mathrm{N}}=1-1.7\right)$ and the tholeiitic magmas $\left((\mathrm{Tb} / \mathrm{Yb})_{\mathrm{N}}=\right.$ 

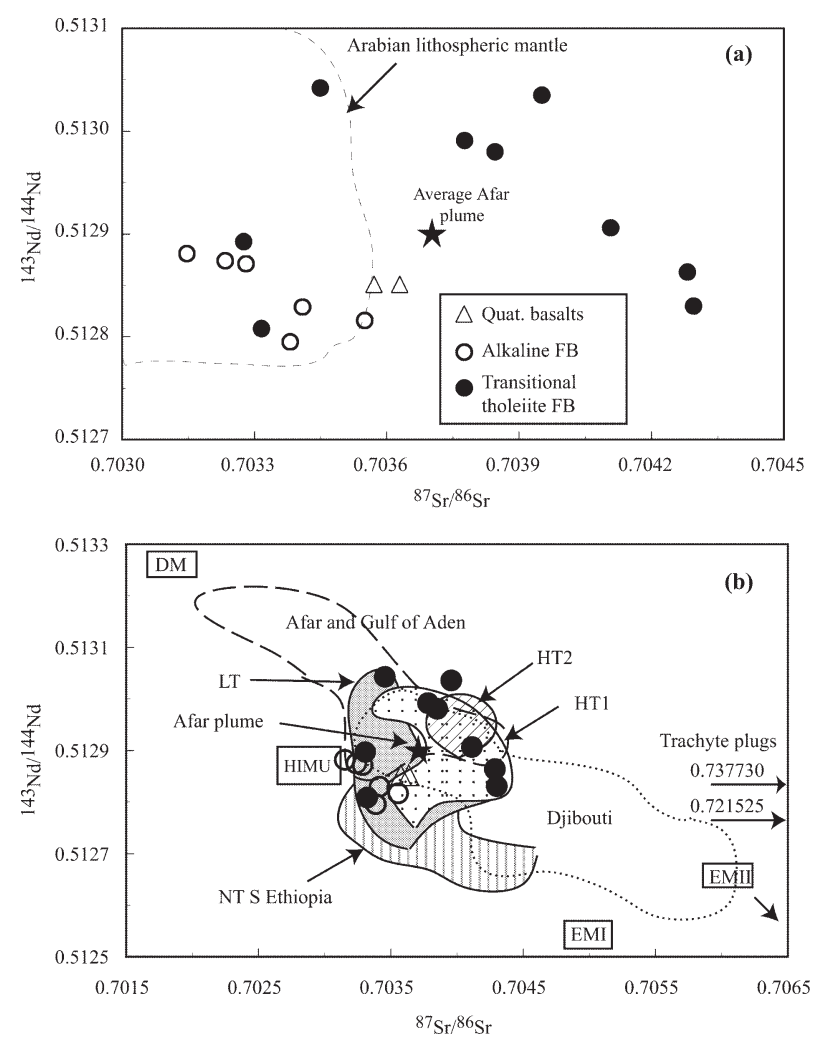

Figure 7. $\mathrm{Sr}-\mathrm{Nd}$ isotope diagram for the Bure volcanic rocks: (a) data for the Bure volcanic rocks and the Arabian lithospheric mantle (Bluztajn et al., 1995) and (b) comparisons with other EARS regional data from Djibouti basalts (Deniel et al., 1994), Afar and Gulf of Aden basalts (Schilling et al., 1992), Low-Ti (LT), Intermediate (HT1) and High-Ti (HT2) basalts in the NW Ethiopian plateau (Pik et al., 1999) and Northern transect basalts of southern (NTS) Ethiopia (Stewart and Rogers, 1996). Depleted (DM), HIMU and Enriched (EMI and EMII) mantle are taken from Zindler and Hart (1986). Trachyte samples plot outside the diagram because of high $\mathrm{Sr}$ isotopic ratios.

1.3-2.2 and $\left.(\mathrm{Dy} / \mathrm{Yb})_{\mathrm{N}}=1.2-1.7\right)$. Both suites have higher MREE/HREE compared with normal mid-ocean ridge basalt (N-MORB) values (Sun and McDonough, 1989). As garnet is the only phase that is likely to fractionate $\mathrm{Tb} / \mathrm{Yb}$ and $\mathrm{Dy} / \mathrm{Yb}$ ratios significantly, and this can happen during partial melting of garnet peridotite within the mantle, the fractionated MREE/HREE signatures of the Bure volcanic rocks suggest that both suites were derived from a source deeper than MORB.

Moreover, chondrite-normalized $\mathrm{La} / \mathrm{Yb}$ and $\mathrm{Ce} / \mathrm{Yb}$ ratios are higher in the alkaline magmas $\left((\mathrm{La} / \mathrm{Yb})_{\mathrm{N}}=4.7-\right.$ 21.5 and $\left.(\mathrm{Ce} / \mathrm{Yb})_{\mathrm{N}}=4.2-14.9\right)$ than in the transitional tholeiitic magmas $\left((\mathrm{La} / \mathrm{Yb})_{\mathrm{N}}=2-6.4\right.$ and $\left.(\mathrm{Ce} / \mathrm{Yb})_{\mathrm{N}}=1.8-6\right)$. This suggests that the alkaline basalts were derived with a lower extent of melting compared with the tholeiitic basalts, if we assume similar incompatible element concentrations for their sources.
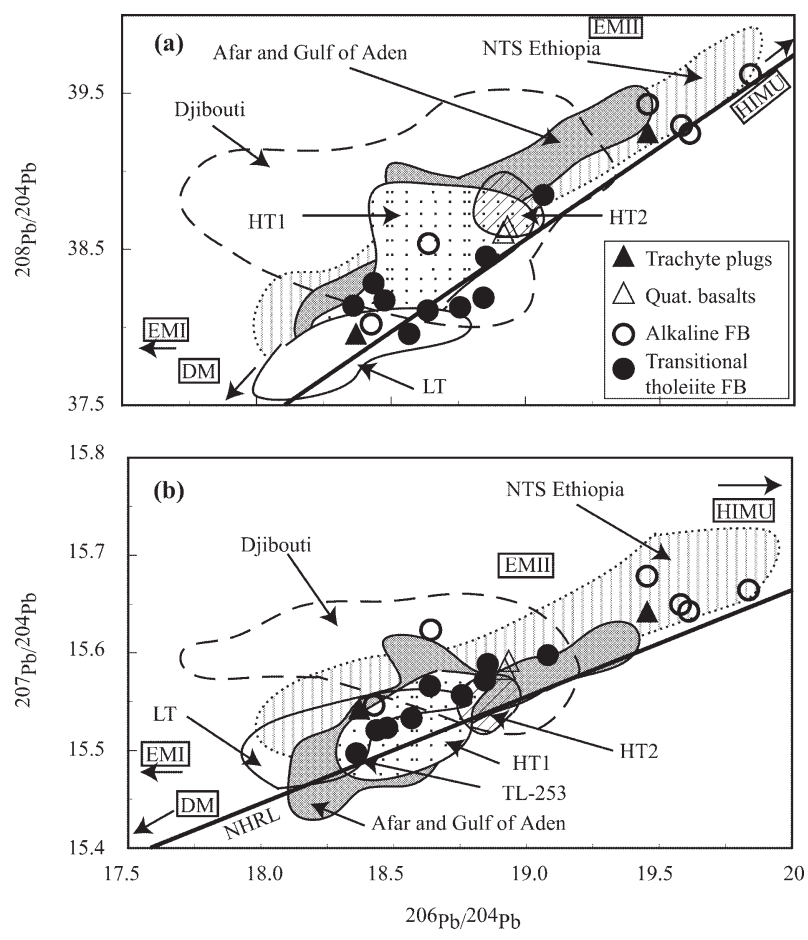

Figure 8. $\mathrm{Pb}$ isotope composition diagrams for the Bure volcanic rocks: (a) ${ }^{206} \mathrm{~Pb} /{ }^{204} \mathrm{~Pb}$ vs ${ }^{208} \mathrm{~Pb} /{ }^{204} \mathrm{~Pb}$ and (b) ${ }^{206} \mathrm{~Pb} /{ }^{204} \mathrm{~Pb}$ vs ${ }^{207} \mathrm{~Pb} /{ }^{204} \mathrm{~Pb}$, in comparison with other EARS regional data from Djibouti basalts (Deniel et al., 1994), Afar and Gulf of Aden basalts (Schilling et al., 1992), Low-Ti (LT), Intermediate (HT1) and High-Ti (HT2) basalts (Pik et al., 1999) and Northern transect basalts of southern (NTS) Ethiopia (Stewart and Rogers, 1996). Depleted (DM), HIMU and Enriched (EMI and EMII) mantle are taken from Zindler and Hart (1986).

\section{Mantle source characteristics and geodynamic impli- cations}

The geochemical variations of the Bure volcanic rocks provide key factors for discussing the interaction process between the Afar plume and the continental crust (Baker et al., 1996; Pik et al., 1999) and/or lithospheric mantle (e.g., Vidal et al., 1991; Schilling et al., 1992; Deniel et al., 1994; Stewart and Rogers, 1996; George and Rogers, 2002). In the previous sections, the combined study of petrology, geochemistry and isotope ratios $(\mathrm{Sr}-\mathrm{Nd}-\mathrm{Pb})$ have shown that different degrees of melting, fractionation, crustal contamination and heterogeneous mantle sources were responsible for the formation of variable geochemical compositions in the Bure volcanic rocks. Our dating results indicate coeval eruption of tholeiitic and alkalic magmas during 30-25 Ma.

As shown in Figure 10 in terms of $\mathrm{Sr}-\mathrm{Nd}-\mathrm{Pb}$ systematics, at least three components can be identified: an "intrinsic" isotopically depleted plume (component I), a plume having a higher $\mathrm{Pb}$ isotope (component II) and a crustal component (component III). The average proposed 

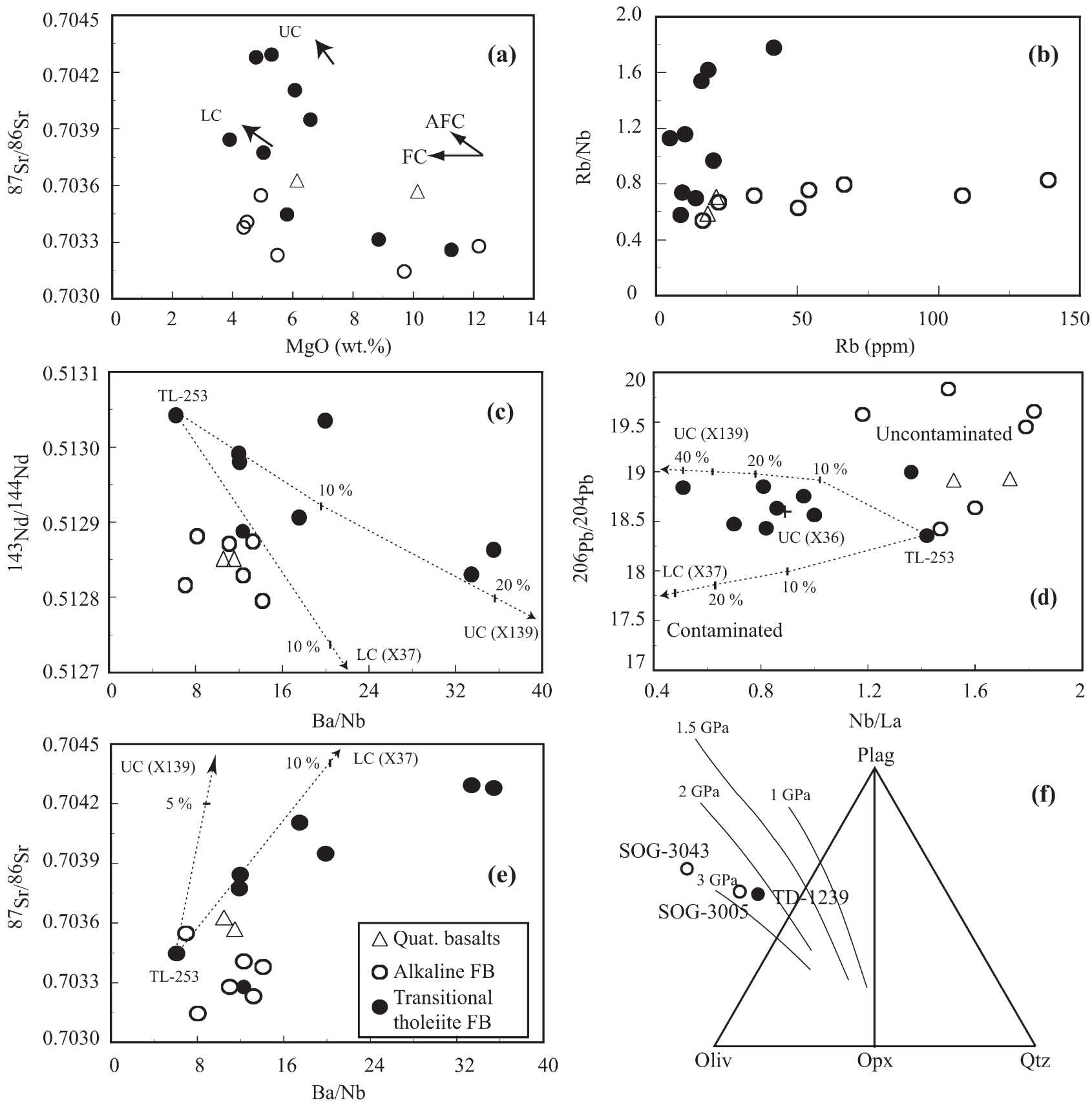

Figure 9. (a) ${ }^{87} \mathrm{Sr} /{ }^{86} \mathrm{Sr}$ vs. $\mathrm{MgO}$, (b) $\mathrm{Rb} / \mathrm{Nb}$ vs. $\mathrm{Rb}$, (c) ${ }^{143} \mathrm{Nd} /{ }^{144} \mathrm{Nd}$ vs. $\mathrm{Ba} / \mathrm{Nb}$, (d) ${ }^{206} \mathrm{~Pb} /{ }^{204} \mathrm{~Pb}$ vs. $\mathrm{Nb} / \mathrm{La}$ and $(\mathrm{e}){ }^{87} \mathrm{Sr} /{ }^{86} \mathrm{Sr}$ vs. Ba/Nb diagrams showing requirement of crustal component and the arrow indicates the inferred trend for lower (LC) and upper crust (UC). The compositions for contaminant UC (X139) ${ }^{87} \mathrm{Sr} /{ }^{86} \mathrm{Sr}=0.727068,{ }^{143} \mathrm{Nd} /{ }^{144} \mathrm{Nd}=0.512052,{ }^{206} \mathrm{~Pb} /{ }^{204} \mathrm{~Pb}=19.035, \mathrm{Sr}=220, \mathrm{Nd}=21.38, \mathrm{~Pb}=67, \mathrm{La}=43.38$, $\mathrm{Nb}=8$ and $\mathrm{Ba}=8$ 88), LC (X37) $\left({ }^{87} \mathrm{Sr} /{ }^{86} \mathrm{Sr}=0.708630,{ }^{143} \mathrm{Nd} /{ }^{144} \mathrm{Nd}=0.511368,{ }^{206} \mathrm{~Pb} /{ }^{204} \mathrm{~Pb}=17.625, \mathrm{Sr}=678, \mathrm{Nd}=34.19, \mathrm{~Pb}=14, \mathrm{La}=\right.$ $61.83, \mathrm{Nb}=7$ and $\mathrm{Ba}=2043)$ and UC (X36) are from Davidson and Wilson (1989). (f) Normative compositions of the most primitive basalts projected onto the Oliv (olivine)-Plag (plagioclase)-Qtz (silica) plane from the diopside apex for the Bure volcanic rocks. Partial melt compositions obtained in peridotite melting experiments at various pressures are from Hirose and Kushiro (1993).

Afar mantle plume (Schilling et al., 1992; Pik et al., 1999; Baker et al., 2000; Rogers et al., 2000) falls within the field defined by these components.

The two components (I and II) can be explained as compositional variation within the plume source. Although one might argue that component I could represent a plume-unrelated ambient (depleted) asthenospheric mantle, its isotopic composition precludes a model involving partial melting of a typical N-MORB mantle source. Moreover, sample TL-253 transitional tholeiitic basalt, which has $\mathrm{Sr}-\mathrm{Nd}-\mathrm{Pb}$ isotopic compositions closer to component I (Fig. 10), does not have incompatible ele- 

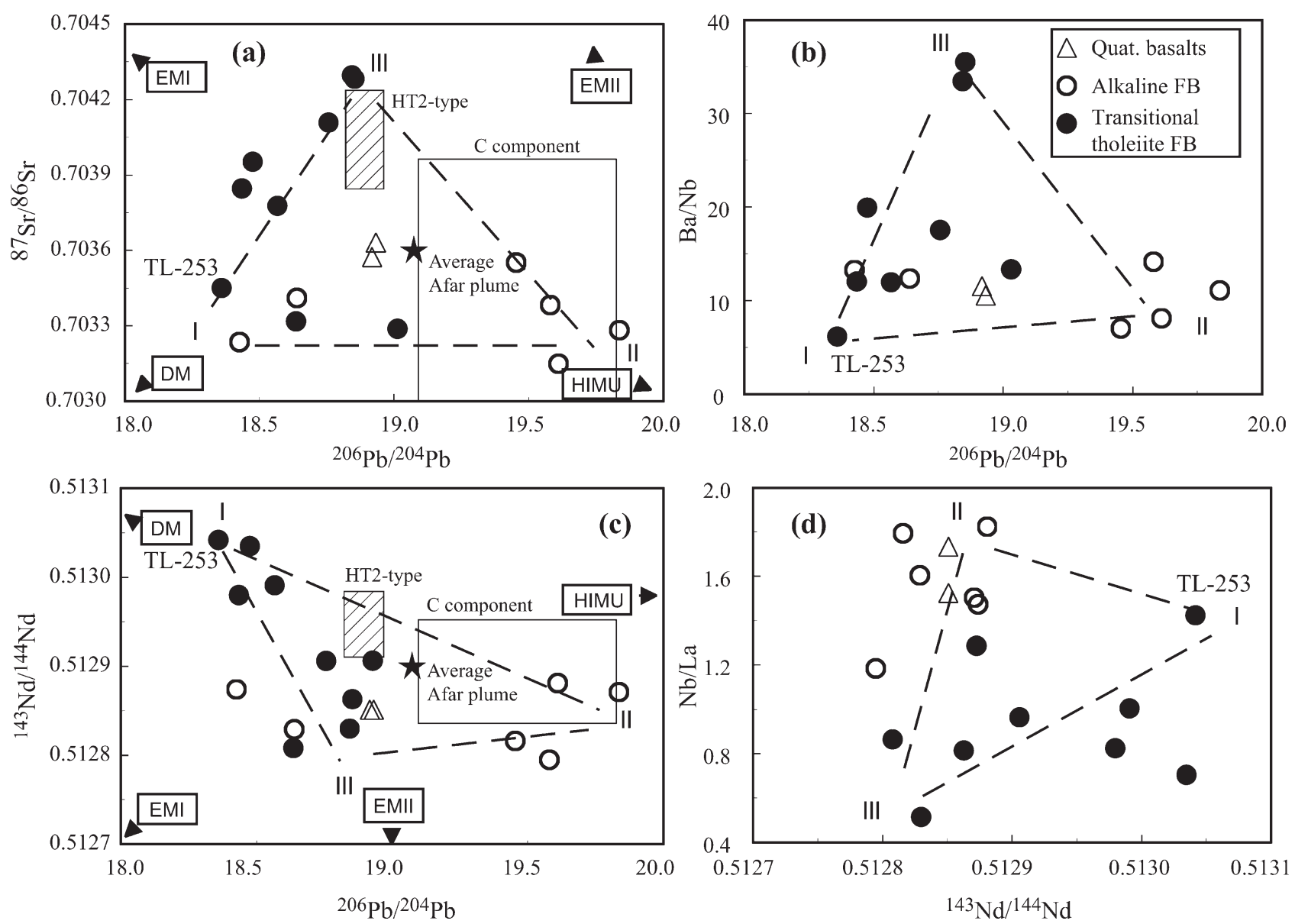

Figure 10. Diagrams of ${ }^{206} \mathrm{~Pb} /{ }^{204} \mathrm{~Pb}$ vs. ${ }^{87} \mathrm{Sr} /{ }^{86} \mathrm{Sr}$ (a), ${ }^{143} \mathrm{Nd} /{ }^{144} \mathrm{Nd}$ (b), Ba/ $\mathrm{Nb}$ (c) and ${ }^{143} \mathrm{Nd} /{ }^{144} \mathrm{Nd}$ vs. $\mathrm{Nb} / \mathrm{La}$ (d). Average Afar plume compositions are taken from Schilling et al., 1992; Pik et al., 1999; Baker et al., 2000; Rogers et al., 2000. Depleted (DM), HIMU and Enriched (EMI and EMII) mantle are taken from Zindler and Hart (1986). I, II and III indicate the possible end-members inferred for geochemical variations of the Bure volcanic rocks. HT2-type basalts and C component fields are from Pik et al. (1999) and Orihashi et al. (2001), respectively.

ment characteristics similar to N-MORB (Fig. 6), and its incompatible element ratios (e.g., $\mathrm{La} / \mathrm{Nb}, \mathrm{Ba} / \mathrm{La}$ and $\mathrm{Zr} / \mathrm{Nb}$ ) are more typical to OIB than N-MORB. Thus, it is reasonable to suggest that the isotopically depleted but trace element-enriched "component I" was derived from a heterogeneous plume mantle source (Fig. 11, model 1).

An alternative interpretation of the component I signature could be a derivation from the lithospheric mantle (Fig. 11, model 2). Indeed, the Arabian lithospheric mantle also displays depleted $\mathrm{Sr}-\mathrm{Nd}$ isotopic ratios (Bluztajn et al., 1995) that overlap with those of the depleted endmember of the transitional tholeiite basalts (Fig. 7). The occurrence of metasomatized mantle xenoliths in the area is also evidence of an interaction between the mantle lithosphere and the fluids and/or magmas released by a deeper upwelling plume (Conticelli et al., 1999). Examples of mafic lavas, which were supposed to have formed within the subcontinental lithosphere rather than within the underlying ambient asthenosphere or a rising mantle plume, have been reported from the Southern Kenya Rift lavas (le Roex et al., 2001; Späth et al., 2001). A distinctive striking feature of these lavas is a strong but variable depletion in $\mathrm{K}$ on mantle-normalized incompatible element patterns, which has been ascribed to the partial melting of a source that contained residual amphibole. The presence of amphibole implies a shallow mantle source and suggests an origin from the subcontinental lithosphere rather than from the deeper asthenosphere. In the Bure lavas, negative $\mathrm{K}$ anomalies in mantle-normalized patterns of the least contaminated tholeiitic basalts are absent (Fig. 6). Therefore, a plume source origin for component I seems more likely.

Component II in Figure 10 is mostly represented by alkaline basalts and characterized by higher ${ }^{206} \mathrm{~Pb} /{ }^{204} \mathrm{~Pb}$ with OIB-like incompatible element ratios. Despite of similar ages of Bure alkaline basalts to the HT2 basalts, plume component II inferred from Bure basalts is isotopically dissimilar to those of HT2-type basalts (Fig. 10a, c). It has been widely accepted that the Oligocene Afar plume composition is best exemplified by the HT2-type 


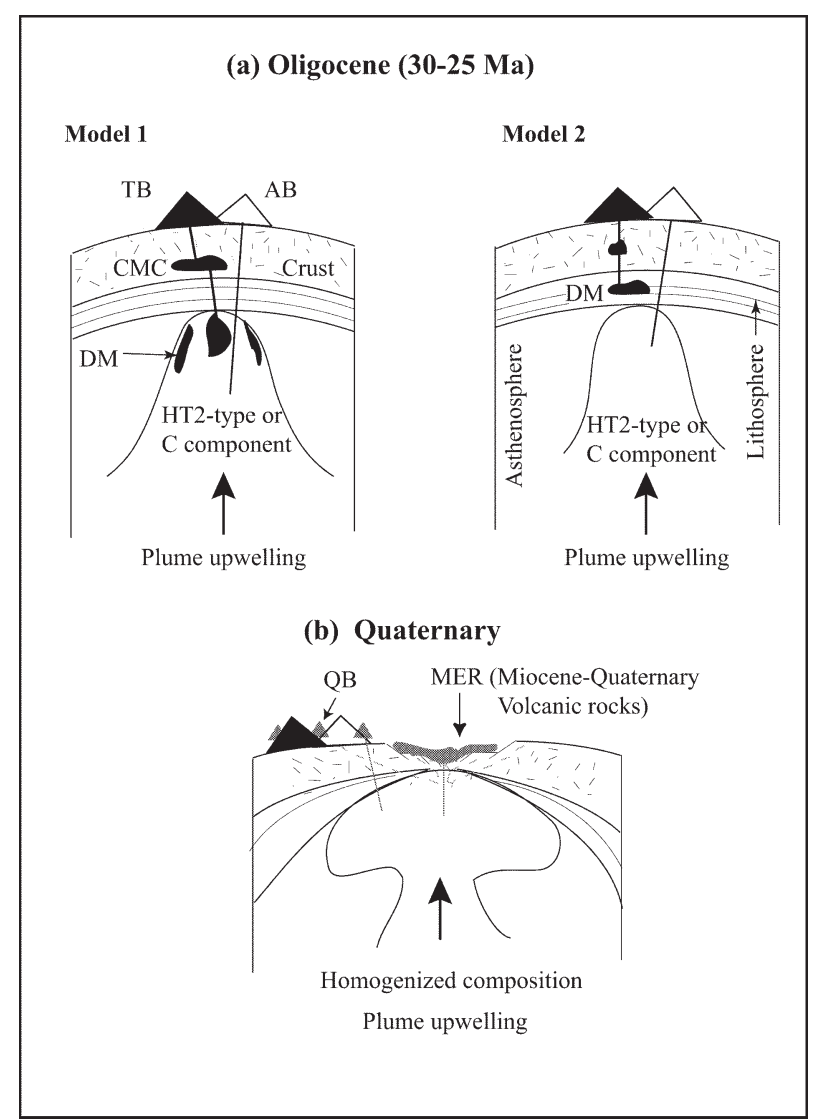

Figure 11. Simplified geodynamic model for the generation of the Bure volcanic rocks, not to scale. TB, Transitional basalts; AB, Alkaline basalts; QB, Quaternary basalts, scoria and trachyte plugs; CMC, Crustal Magma Chamber, MER, Main Ethiopian Rift.

basalts (Pik et al., 1999, 2006). On the other hand, Orihashi et al. (2001) have argued that "younger" (late Miocene to Recent) basalts from Yemen, Afar and Gulf of Aden region require three components: upper mantle (DM), enriched Pan-African lithospheric mantle (ELM) and an intermediate component between DM and HIMU. The intermediate component as the Afar mantle plume has the $\mathrm{Sr}, \mathrm{Nd}$ and $\mathrm{Pb}$ isotope variation of the common component $(\mathrm{C}$ or focal zone $(\mathrm{FOZO}))\left({ }^{143} \mathrm{Nd} /{ }^{144} \mathrm{Nd}=0.51284-\right.$ $0.51295,{ }^{87} \mathrm{Sr} /{ }^{86} \mathrm{Sr}=0.7030-0.7040$ and ${ }^{206} \mathrm{~Pb} /{ }^{204} \mathrm{~Pb}=$ 19.2-19.8) rather than the HIMU component (Orihashi et al., 2001); this composition is also shown in Figures 10a and c. The Bure plume component II clearly overlaps the C component for the "younger" Afar plume. Because the Bure alkaline basalts are dated as Oligocene, the temporal change in isotope composition from HT2-type basalt-like to $\mathrm{C}$ component for the Afar plume cannot be validated. Instead, all these observations imply a highly heterogeneous nature for the Oligocene Afar plume at the initial stage of plume impingement.

Component III represents the enriched end-member of the transitional tholeiite basalts, which trend towards crustal rock compositions. In addition, the rocks display incompatible trace element and isotope ratios (e.g., high $\mathrm{Ba} / \mathrm{Nb}$, low $\mathrm{Nb} / \mathrm{La}$, unradiogenic $\mathrm{Pb}$ and radiogenic $\mathrm{Sr}$ ) consistent with crustal additions similar to LT-type basalts (Pik et al., 1998, 1999) and Yemen basalts (Baker et al., 1996). Plume upwelling initiated crustal extension in the middle to late Oligocene (e.g., White et al., 1989; Vidal et al., 1991; Schilling et al., 1992; Ebinger and Sleep, 1998; Pik et al., 1999) and the injection of isotopically depleted melt into the crustal chamber (Fig. 11, model 1), where AFC processes might have played an important role.

Subsequent plume upwelling induced rifting. MioceneQuaternary magmas that originated from the plume source have been mostly confined to the MER and Afar regions (Fig. 11b). The Bure Quaternary volcanic rocks (basaltic lava, scoria and trachyte plugs) are also related to the last stage of rift development. Quaternary alkaline basalts have isotopic compositions that are different from those of Oligocene alkaline basalts but intermediate among component I, II and HT2-type basalts; Quaternary magmas might have been derived from a more homogenized plume source.

\section{CONCLUSIONS}

1. The Bure volcanic rocks are composed of two distinct volcanic suites: transitional tholeiite and alkaline CFBs. The eruptive sequence is voluminous transitional tholeiite and alkaline CFBs in the plateau-forming stage (30-25 Ma) followed by a minor amount of Quaternary alkaline single lava flow, scoria cones and highly fractionated trachyte plugs. The general successions of the erupted basalts are from hypersthenequartz normative transitional tholeiites to nephelineolivine normative alkaline basalts, although our new age data suggest coeval eruption of tholeiitic and alkaline lavas.

2. The isotopic ratio and trace element characteristics of the transitional tholeiite basalts are variable and more heterogeneous than the alkaline basalts. The transitional tholeiite basalts are characterized by higher incompatible element ratios (e.g., $\mathrm{Ba} / \mathrm{Nb}$ and $\mathrm{Rb} / \mathrm{Nb}$ ), ${ }^{87} \mathrm{Sr} /{ }^{86} \mathrm{Sr}$ and unradiogenic $\mathrm{Pb}$ isotopes. These signatures can be explained by crustal contamination of the magmas. On the other hand, the alkaline basalt suite has a composition of homogeneous incompatible trace element ratios, low ${ }^{87} \mathrm{Sr} /{ }^{86} \mathrm{Sr}$ and more radiogenic $\mathrm{Pb}$ isotopes, which indicates that the alkaline basalts originated from a more enriched OIB-like Afar plume source with a low degree of partial melting. The crustal 
effect was hardly observed in this suite. It is not clear why only the tholeiitic magmas suffered considerable crustal contamination.

3. We identify at least two mantle components that have distinctive $\mathrm{Sr}-\mathrm{Nd}-\mathrm{Pb}$ isotopic ratios (an intrinsic isotopically depleted plume component and a plume component having radiogenic $\mathrm{Pb}$ isotope); these two components clearly differ from the component observed in HT2-type basalts. We infer that both components originated in the upwelling plume source, due to heterogeneous nature of Afar mantle plume.

\section{ACKNOWLEDGMENTS}

D. M. thanks the Japanese Ministry of Education, Culture, Sports, Science and Technology (MEXT) for a scholarship from the "Special Graduate Program for International Students" in the University of the Ryukyus. We appreciate S. Ohde (University of the Ryukyus) for assistance with TIMS and ICP-MS analyses. We acknowledge the journal reviewers (Y. Orihashi and T. Hanyu) and the associate editor (J.-I. Kimura) for their valuable comments. Finally, we would like to thank the Geological Survey of Ethiopia (GSE), in particular the staff of the Regional Geology and Geochemistry Department of the GSE, for their comprehensive support. This work was supported by the MEXT grant 17540458 (C) to R. S.

\section{REFERENCES}

Abebe, T., Mazzarini, F., Innocentti, F. and Manetti, P. (1998) The Yerer-Tullu Wellel volcano-tectonic Lineament: a transtentional structure in central Ethiopia and the associated magmatic activity. Journal of African Earth Sciences, 26, 135150.

Baker, J., Thirlwall, M. and Menzies, M. (1996) $\mathrm{Sr}-\mathrm{Nd}-\mathrm{Pb}$ isotopic and trace element evidence for crustal contamination of plume-derived flood basalts: Oligocene flood volcanism in western Yemen. Geochimica et Cosmochimica Acta, 60, 2559-2581.

Baker, J., MacPherson, C.G., Menzies, M.A., Thirlwall, M.F., AlKadasi, M. and Mattey, D.P. (2000) Resolving crustal and mantle contributions to continental flood volcanism, Yemen; constraints from mineral oxygen isotope data. Journal of Petrology, 41, 1805-1820.

Barrat, J.A., Fourcade, S., Jahn, B.M., Chemirke, J.L. and Capdevila, R. (1998) Isotope ( $\mathrm{Sr}, \mathrm{Nd}, \mathrm{Pb}, \mathrm{O})$ and trace-element geochemistry of volcanics from the Erta' Ale range (Ethiopia). Journal of Volcanology and Geothermal Research, $80,85-100$.

Barrat, J.A., Joron, J.L., Taylor, R.N., Fourcade, S., Nesbitt, R.W. and Jahn, B.M. (2003) Geochemistry of basalts from Manda Hararo, Ethiopia: LREE-depleted basalts in Central Afar. Lithos, 69, 1-13.

Berhe, S., Desta, B., Nicoletti, M. and Tefera, M. (1987) Geology, geochronology and geodynamic implications of the Cenozoic magmatic province in $\mathrm{W}$ and SE Ethiopia. Journal of Geological Society of London, 144, 213-226.

Bluztajn, J., Hart, S.R., Shimizu, N. and McGuire, A.V. (1995) Trace element and isotopic characteristic of spinel peridotite xenoliths from Saudi Arabia. Chemical Geology, 123, 53-65.

Conticelli, S., Sintoni, M.F., Abebe, T., Mazzarini, F. and Manetti, P. (1999) Petrology and geochemistry of ultramafic xenoliths and host lavas from the Ethiopian volcanic province: an insight into the upper mantle under east Africa. Acta Volcanologica, 11, 143-159.

Davidson, A. and Rex, D.C. (1980) Age of volcanism and rifting in southern Ethiopia. Nature, 283, 65-66.

Davidson, J.P. and Wilson, I.R. (1989) Evolution of an alkali basalttrachyte suite from Jebel Marra volcano, Sudan, through assimilation and fractional crystallization. Earth and Planetary Science Letters, 95, 141-160.

Deniel, C., Vidal, P., Coulon, C., Vellutini, P.J. and Piguet, P. (1994) Temporal evolution of mantle sources through continental rifting: The volcanism of Djibouti (Afar). Journal of Geophysical Research, 99, 2853-2869.

DePaolo, D.J. (1981) Trace element and isotopic effects of combined wallrock assimilation and fractional crystallization. Earth and Planetary Science Letters, 53, 189-202.

DePaolo, D.J. and Daley, E.E. (2000) Neodymium isotopes in basalts of the southwest basin and range and lithospheric thinning during continental extension. Chemical Geology, 169, 157-185.

Ebinger, C.J. and Sleep, N.H. (1998) Cenozoic magmatism throughout east Africa resulting from impact of a single plume. Nature, 395, 788-791.

George, R.M. and Rogers, N.W. (2002) Plume dynamics beneath the African plate inferred from the geochemistry of the Tertiary basalts from southern Ethiopia. Contributions to Mineralogy and Petrology, 144, 286-304.

Hart, S.R. (1984) A large-scale isotope anomaly in the southern hemisphere mantle. Nature, 309, 753-757.

Hart, W.K., Woldegabriel, G., Walter, R.C. and Mertzman, S.A. (1989) Basaltic volcanism in Ethiopia: Constraints on continental rifting and mantle interactions. Journal of Geophysical Research, 94, 7731-7748.

Hirose, K. and Kushiro, I. (1993) Partial melting of dry peridotites at high pressures: determination of compositions of melt segregated from peridotite using aggregates of diamond. Earth and Planetary Science Letters, 114, 477-489.

Hofmann, C., Courtillot, V., Féraud, G., Rochette, P., Yirgu, G., Ketefo, E. and Pik, R. (1997) Timing of the Ethiopian flood basalt event and implications for plume birth and global change. Nature, 389, 838-841.

Irving, T.N. and Baragar, W.R.T. (1971) A guide to the chemical classification of the common rocks. Canadian Journal of Earth Sciences, 8, 523-548.

Itaya, T., Nagao, K., Inoue, K., Honjou, Y., Okada, T. and Ogata, A. (1991) Argon isotope analysis by a newly developed mass spectrometric system for $\mathrm{K}-\mathrm{Ar}$ dating. Mineralogical Journal, $15,203-221$.

Kazmin, V. (1972) Geological map of Ethiopia, scale 1:2,000,000. Ethiopian Institute of Geological Survey, Addis Ababa, Ethiopia.

Kazmin, V. (1979) Stratigraphy and Correlation of Cenozoic Volcanic Rocks in Ethiopia. Reports of Ethiopian Institute of Geological Survey, 106, 1-26.

Kieffer, B., Arndt, N., Lapierre, H., Bastien, F., Bosch, D., Pecher, 
A., Yirgu, G., Ayalew, D., Weis, D., Jerram, D.A., Keller, F. and Meugniot, C. (2004) Flood and Shield Basalts from Ethiopia: Magmas from the African Superswell. Journal of Petrology, 45, 793-834.

Kushiro, I. (1994) Recent experimental studies on partial melting of mantle peridotites at high pressures using diamond aggregates. Journal of Geological Society of Japan, 100, 103-110.

Le maitre, R.W., Bateman, P., Dudek, A., Kellar, J., Lameyre Le Bas, M.J., Sabine, P.A., Schmid, R., Sorensen, H., Streckeisen, A., Woolley, A.R. and Zanettin, B. (1989) A classification of igneous rocks and glossary of terms. pp. 193, Blackwell, Oxford, UK.

le Roex, A.P., Späth, A. and Zartman, R.E. (2001) Lithospheric thickness beneath the southern Kenya Rift: implications from basalt geochemistry. Contributions to Mineralogy and Petrology, 142, 89-106.

Meshesha, A.D. and Shinjo, R. (2004) Petrochemical evidence for diversity of magma compositions at the northwestern Ethiopian volcanic province. Bulletin of the Faculty of Science, University of the Ryukyus, 78, 251-266.

Mohr, P.A. (1963) The Geology of Ethiopia. pp. 268, Addis Ababa University Press, Addis Ababa, Ethiopia.

Mohr, P. and Zanettin, B. (1988) The Ethiopian flood basalt province. In Continental flood basalts (McDougall, J.D. Ed.). Kluwer Acadamic Publication, Dordrecht, 63-110.

Nagao, K., Nishido, H., Itaya, T. and Ogata, K. (1984) An age determination by $\mathrm{K}-\mathrm{Ar}$ method, Bull. Hiruzen Research Institute, 9, 19-38 (in Japanese with English abstract).

Orihashi, Y., Nagao, K., Al-Jailani, A. and Hanan, B.B. (2001) Primordial helium isotope signature from Plio-Quaternary alkaline basalts in Yemen. The Island Arc, 10, 145-157.

Pik, R., Deniel, C., Coulon, C., Yirgu, G., Hoffmann, C. and Ayalew, D. (1998) The northwestern Ethiopian Plateau flood basalts: Classification and spatial distribution of magma types. Journal of Volcanology and Geothermal Research, 81, 91-111.

Pik, R., Deniel, C., Coulon, C., Yirgu, G., Hoffmann, C. and Ayalew, D. (1999) Isotopic and trace element signatures of Ethiopian flood basalts: evidence for plume-lithosphere interactions. Geochimica et Cosmochimica Acta, 63, 2263-2279.

Pik, R., Marty, B. and Hilton, D.R. (2006) How many mantle plumes in Africa? The geochemical point of view. Chemical Geology, 226, 100-114.

Rogers, N., Macdonald, R., Fitton, J.D., George, R., Smith, M. and Barreiro, B. (2000) Two mantle plumes beneath the East African rift system: $\mathrm{Sr}, \mathrm{Nd}$ and $\mathrm{Pb}$ isotope evidence from Kenya Rift basalts. Earth and Planetary Science Letters, 176, 387-400.

Schilling, J.G., Kingsley, R.H., Hanan, B.B. and McCully, B.L. (1992) $\mathrm{Nd}-\mathrm{Sr}-\mathrm{Pb}$ isotopic variations along the Gulf of Aden: Evidence for mantle plume-continental lithosphere interac- tion. Journal of Geophysical Research, 97, 10927-10966.

Shinjo, R., Woodhead, J.D. and Hergt, J.M. (2000) Geochemical variation within the northern Ryukyu Arc: magma source compositions and geodynamic implications. Contributions to Mineralogy and Petrology, 140, 263-282.

Späth, A., Le Roex, A.P. and Opiyo-Akech, N. (2001) Plume-lithosphere interaction and the origin of continental rift-related alkali volcanism - the Chyulu Hills volcanic province, southern Kenya. Journal of Petrology, 42, 765-787.

Steiger, R.H. and Jäger, E. (1977) Subcommission on geochronology: Convention on the use of decay constants in geo- $^{-}$and cosmochronology. Earth and Planetary Science Letters, 36, 359-362.

Stewart, K. and Rogers, N. (1996) Mantle plume and lithosphere contributions to basalts from southern Ethiopia. Earth and Planetary Science Letters, 139, 195-211.

Sun, S.S. and McDonough, W.F. (1989) Chemical and isotopic systematics of oceanic basalts: implications for mantle composition and processes. In Magmatism in oceanic basins (Saunders, A.D. and Norry, M.J. Eds.). Geological Society of London, Special Publication, 42, 313-345.

Tefera, M., Chernet, T. and Haro, W. (1996) Geological map of Ethiopia, scale 1:2,000,000. Ethiopian Institute of Geological Surveys, Addis Ababa, Ethiopia.

Thirlwall, M.F. (2000) Inter-laboratory and other errors in Pb isotope analyses investigated using a ${ }^{207} \mathrm{~Pb}-{ }^{204} \mathrm{~Pb}$ double spikes. Chemical Geology, 163, 299-322.

Thompson, R.N., Morrison, M.A., Dickin, A.P. and Hendry, G.L. (1983) Continental flood basalts...arachnids rule OK? In Continental Basalts and Mantle Xenoliths (Hawkesworth, C.J. and Norry, M.J. Eds). Shiva Pub., Cambridge, USA, 158185.

Vidal, P., Deniel, C., Vellutini, P.J., Piguet, P., Coulon, C., Vincent, J. and Audin, J. (1991) Changes of mantle sources in the course of a rift evolution: the Afar case. Geophysical Research Letters, 18, 1913-1916.

Walker, D., Shibata, T. and Bender, J.F. (1979) Abyssal tholeiites from the Oceanographer fracture zone. II, Phase equilibria and mixing. Contributions to Mineralogy and Petrology, 70, 111-125.

White, R. and McKenzie, D. (1989) Magmatism at Rift Zones: The Generation of Volcanic Continental Margins and Flood Basalts. Journal of Geophysical Research, 94, 7685-7729.

Zindler, A. and Hart, S.R. (1986) Chemical geodynamics. Annual Review of Earth and Planetary Science, 14, 493-571.

\author{
Manuscript received November 29, 2006 \\ Manuscript accepted March 9, 2007 \\ Published online June 8, 2007 \\ Manuscript handled by Jun-ichi Kimura
}




\section{APPENDIX}

\section{K-Ar age dating analytical method}

Groundmass separates, concentrated by means of magnetic separation, were analyzed for $\mathrm{K}$ and $\mathrm{Ar}$ at the Hiruzen Institute for Geology and Chronology Co. Ltd. (Japan) and calculations of ages and errors were determined using the methods described by Nagao et al. (1984) and Itaya et al. (1991). The accuracy and reproducibility of these methods were within $2 \%$. Decay constants $\lambda \mathrm{e}=0.581 \times 10^{-10} / \mathrm{yr}, \lambda \beta=4.962 \times 10^{-10} / \mathrm{yr}$ and ${ }^{40} \mathrm{~K} / \mathrm{K}=1.167 \times 10^{-4}$ are from Steiger and Jäger (1977). The results are presented in the table below.

Appendix. $\mathrm{K}-\mathrm{Ar}$ age dating results for representative Bure volcanic rocks

\begin{tabular}{|c|c|c|c|c|c|c|c|c|c|c|c|}
\hline \multirow{3}{*}{$\begin{array}{l}\text { Sample } \\
\text { No. } \\
\text { TD-1228A }\end{array}$} & \multirow{3}{*}{$\frac{\text { Rock type }}{\text { TB }}$} & \multicolumn{2}{|c|}{ Location } & \multirow{3}{*}{$\begin{array}{c}\begin{array}{c}\mathrm{K}_{2} \mathrm{O} \\
\text { (wt. \%) }\end{array} \\
0.527\end{array}$} & \multirow{2}{*}{\multicolumn{3}{|c|}{$\begin{array}{c}\text { Rad. }{ }^{40} \mathrm{Ar} \\
\left(10^{-8} \mathrm{cc} \mathrm{STP} / \mathrm{g}\right)\end{array}$}} & \multirow{3}{*}{$\begin{array}{c}\text { Non-rad. } \\
{ }^{40} \mathrm{Ar}(\%)\end{array}$} & \multirow{2}{*}{\multicolumn{3}{|c|}{$\begin{array}{c}\text { K-Ar age } \\
\text { (Ma) }\end{array}$}} \\
\hline & & \multirow{2}{*}{$\begin{array}{c}\text { Latitude (N) } \\
10^{\circ} 56^{\prime} 54^{\prime \prime}\end{array}$} & \multirow{2}{*}{$\begin{array}{c}\text { Longitude (E) } \\
37^{\circ} 25^{\prime} 06^{\prime \prime}\end{array}$} & & & & & & & & \\
\hline & & & & & 60.30 & \pm & 0.62 & & 29.26 & \pm & 0.65 \\
\hline TD-1202 & TB & $10^{\circ} 33^{\prime} 12^{\prime \prime}$ & $37^{\circ} 11^{\prime} 45^{\prime \prime}$ & 0.393 & 40.87 & \pm & 0.58 & 29.0 & 26.60 & \pm & 1.40 \\
\hline SOG-3005 & $\mathrm{AB}$ & $10^{\circ} 50^{\prime} 43^{\prime \prime}$ & $36^{\circ} 36^{\prime} 55^{\prime \prime}$ & 0.758 & 84.00 & \pm & 1.10 & 24.4 & 28.34 & \pm & 0.67 \\
\hline TD-1034B & $\mathrm{AB}$ & $10^{\circ} 38^{\prime} 57^{\prime \prime}$ & $37^{\circ} 28^{\prime} 49^{\prime \prime}$ & 1.023 & 101.5 & \pm & 1.00 & 7.10 & 25.27 & \pm & 0.56 \\
\hline
\end{tabular}

STP, standard temperature and pressure; Rad. ${ }^{40} \mathrm{Ar}$, radiogenic ${ }^{40} \mathrm{Ar}$; Non-rad ${ }^{40} \mathrm{Ar}$, percent of nonradiogenic ${ }^{40} \mathrm{Ar}$; TB, Tholeiite flood basalts; $\mathrm{AB}$, Alkaline flood basalts. 